\title{
En torno a la circulación observada desde la Aduana de Buenos Aires entre 1779 y 1783
}

\author{
Around the circulation observed from the \\ Customs of Buenos Aires between 1779 and 1783 \\ Fernando Jumar ${ }^{1}$ ii \\ CONICET / Inst. de Est. Históricos (UNTreF) - Academia Nacional de la Historia - Argentina
}

\begin{abstract}
RESUMEN
Se presenta la fuente principal utilizada en otro trabajo y su tratamiento, así como la crítica de los datos emergentes en función de su construcción, de la coyuntura y de las diversas formas del fraude fiscal. De la última variable ponderada, emerge una hipótesis que vincula consumo y estratificación social en los espacios observados.
\end{abstract}

Palabras clave: Río de la Plata; siglo XVIII; circulación interior; consumo; espacio económico.

Para citaciones: Jumar, F. (2020). En torno a la circulación observada desde la Aduana de Buenos Aires entre 1779 y 1783 . El taller de la Historia, 12(1), 108-145. DOI: 10.32997/23824794-vol.12-num.1-2020-3204

Recibido: abril de 2019

Aprobado: septiembre de 2019

Editor: Sergio Paolo Solano. Universidad de Cartagena-Colombia.

Tipología IBN Publindex:

Artículo de Investigación

Copyright: ( $\odot$ 2020. Jumar, F. Este es un artículo de acceso abierto, distribuido bajo los términos de la licencia https://creativecommons.org/licenses/by-nc$\underline{\mathrm{sa} / 4.0 / \text { la cual permite el uso sin restricciones, }}$ distribución y reproducción en cualquier medio, siempre y cuando que el original, el autor y la fuente sean acreditados.

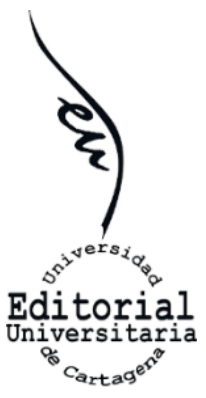

\section{ABSTRACT}

The main source used in other work and its treatment is presented, as well as the criticism of the emerging data depending on its construction, the period and the various forms of tax fraud. From the last weighting variable, a hypothesis emerges that links consumption and social stratification in the observed spaces.

Keywords: Río de la Plata; XVIIIth century; inner circulation; consumption; economic space.

\section{PRESENTACIÓN}

En un artículo publicado en el número 11 de El Taller de la Historia se presentaron datos sobre la circulación vista desde la Aduana de Buenos Aires entre 1779 y $1783^{2}$. Razones de espacio no permitieron en esa ocasión presentar la fuente principal utilizada y su tratamiento, ni la crítica de las cifras obtenidas, de las que emerge una hipótesis en torno al papel del consumo en la articulación de los mercados americanos y extra-americanos en función de preguntas relacionadas con la estratificación social. Con lo que el presente trabajo completa tanto el mencionado artículo como el dossier del que formó parte.

\section{1.- La fuente principal y su tratamiento}

\section{La fuente}

La elaboración de las series que se emplearon para el seguimiento de la circulación vista desde la Aduana de Buenos Aires entre 1779 y 1783 está estructurada en torno a la explotación de un documento de origen fiscal, las notas

\footnotetext{
1 fjumar@ conicet.gov.ar

2 Fernando Jumar, "Hay para todos. La circulación intra y extra-regional de Río de la Plata observada desde la Aduana de Buenos Aires, 1779-1783", en El Taller de la Historia, 12, 2019, pp. 267-315.
} 
de aduana ${ }^{3}$. Es la fuente de información básica que desagregada y progresivamente sintetizada se encuentra en los diversos libros de la Real Hacienda relacionados con la percepción de derechos sobre la circulación. Lo que no pagó derechos, se recupera en las notas pero se pierde en el resto de las fuentes fiscales. Son documentos convertibles en fuente de diversas observaciones que superan su primera dimensión fiscal.

Liberados gracias a la informática del trabajo manual para construir las series y de la regla de cálculo y del papel milimetrado o logarítmico para los gráficos ${ }^{4}$, lo enormemente engorroso de esta investigación puntual se relaciona con la identificación de los productos puestos en circulación en función de su origen, calidad y consumo potencial. A ello se superponen problemas relacionados con la metrología, dada la necesidad de reducir a comunes denominadores sistemas distintos aplicados a los mismos bienes; ha causado buenos dolores de cabeza, y aún no se ha logrado doblegarla en todos los casos ${ }^{5}$. También son densos los desafíos relacionados con el precio de los bienes registrados. Es tema de otra investigación en curso de largo aliento basada en fuentes privadas ${ }^{6}$, ya que comparto las desconfianzas existentes sobre los valores de aforo como reflejo de precios de mercado ${ }^{7}$.

\footnotetext{
${ }^{3}$ Cuando por algún motivo no se pudo procesar una nota de aduana o no se encontraron paneles de información, se recurrió al "Libro Real particular donde se asientan las Guías de referencia, en que se despachan por esta Real Aduana todos los Géneros, y Frutos, así de España como Extranjeros, y del País para las Provincias interiores del Reyno, Montevideo, y demás Puestos de la otra Banda de este Río; igualmente, que para los Registros que regresan a España, y cuyas partidas van numeradas, como las mismas Guías...". Estos libros contienen menos información que las notas, que afectarían la observación si se la quiere realizar a través de los precios de aforo, ya que no suelen diferenciar el pago de derechos por bien sino que se da el total devengado por la operación. También se pierden de la observación el detalle, como podría ser los distintos colores de las piezas de un determinado textil (si se tasan sobre la misma base, se consigna el agregado), etc. y, sobre todo, lo que se pone en circulación y no debió pagar derechos.

${ }_{4}^{4}$ Para quienes no recuerden o no puedan recordar por no haberlo vivido, invito a mirar la tesis de Licenciatura de Juan Carlos Garavaglia de 1970 y verán esos gráficos en papel milimetrado. J. C. Garavaglia, El comercio virreinal 1779-1784, Tesis de licenciatura inédita, Universidad de Buenos Aires, 1970, pp. 23-24. A quienes no pueden recordar tal vez no sea imprudente comentarles que las dificultades técnicas del pasado aumentan el valor de la historia seriada previa a la democratización de la ofimática. También explican mucho de su hechura, con series cortas, de costosa elaboración, y modelos teóricos para completar el cuadro. En esos trabajos las series validan modelos teóricos, en la actualidad las series intervienen en la construcción de los modelos.

${ }^{5}$ Hay un rubro dentro de la familia de los textiles, los hilos, de enorme importancia por su presencia en las fuentes (medida por la cantidad de envíos y la diversidad detectada) que aún resisten todo intento de cuantificación uniformizada.

${ }^{6}$ En la línea de un trabajo realizado por Fernando Barba y aunque no es la metodología recomendada para hacer historia de precios, se están acumulando datos contenidos en todo tipo de documentación privada (principalmente correspondencia, libros de caja y contratos; accesoriamente tasaciones de inventarios post mortem) por considerarlos mejor reflejo del mercado que las series de precios de instituciones religiosas. Fernando Enrique Barba, Aproximación al estudio de los precios y salarios en Buenos Aires desde fines del siglo XVIII hasta 1860. Series y problemas en torno al tratamiento de los mismos, La Plata, Editorial de la UNLP/Fundación del Banco Municipal de La Plata, 1999. Para una postura contraria, ver: Julio César Djenderedjian, Carina Frid y Juan Luis Martirén, "Los registros conventuales como fuente para la historia económica. Aproximaciones metodológicas a partir del caso de Santa Fe (Argentina), 1700-1850", en Historia Crítica, 72, 2019, pp. 3-25.

${ }^{7}$ Los valores de aforo son resultado de una negociación entre los comerciantes y el poder para percibir los derechos que correspondiera y decidí no usarlos. Esos precios hablan de la fuerza relativa de las partes en las negociaciones fiscales antes que del mercado. Sobre ellos Juan Carlos Garavaglia sostiene que los precios de aforo de los cueros "reflejan, como era de esperar, no el precio real sino el estimado y aun cuando nos den una cierta idea acerca del movimiento de los precios, creemos sin embargo que la serie es defectuosa por varias razones: a) es muy poco elástica, es decir reacciona tardíamente frente a la rapidez del cambio de los precios en determinados momentos; b) toma muy poco en cuenta las diferencias de calidad del producto embarcado; c) lo que es aún más grave, no toma en cuenta las diferencias de peso de los cueros [...]" En relación a los aforos de los bienes extra-americanos puestos en circulación por Buenos Aires, "se afirma con más fuerza lo dicho para el rubro anterior. Los aforos aduaneros no parecen servir para registrar los movimientos de los precios de las mercaderías europeas, pues a lo expresado anteriormente se debe agregar la dificultad para reconocer si se trata de la misma clase, en cuanto a calidad por ejemplo, cuando se nos habla de un producto aparentemente idéntico." J. C. Garavaglia, "El comercio virreinal", p. 5. Por su parte, Mariano Schlez, verifica los desfasajes entre los aforos y los precios en un estudio centrado en un comerciante activo en el período estudiado. Mariano Martín Schlez, "El comercio de un monopolista. Volumen, contenido y sentido de la circulación según un estudio de caso (Río de la Plata, 1770-1820)”. Anuario de Estudios Americanos, 73, 1, 2016, pp. 163-198. Para una opinión distinta sobre la utilidad de los precios de aforo, ver: Julio Djenderedjian y Juan Luis Martirén, "Los aforos de alcabalas como fuente útil para el estudio de los precios en el Río de la
} 
Una nota de aduana se origina cuando toda persona física o moral que quería desplazarse hacia otro lugar, por el motivo que fuese, con o sin bienes, o quería remitir bienes a otra, con fines mercantiles o no, debía dirigirse a quien fungiese en su comarca como representante del Erario Real (en Buenos Aires el Administrador General de la Aduana) mediante una nota que debía tener una serie de informaciones mínimas. La nota presentada contiene, entonces, dos partes. En la primera parte, el declarante (por sí o a través de un representante), dirigiéndose al Administrador General de la Aduana, daba las informaciones generales del caso: quién, a quién o a sí mismo, adónde, motivo bajo el que se mueven los bienes (cuando se lo especifica), en qué medio de transporte y a cargo de quién. La fuente contiene excesos de información en función de lo requerido que aparecen de modo muy irregular pero que son siempre bienvenidos porque permiten percibir diversos aspectos relacionados con el envío en cuestión (p. e. informaciones sobre a quién se compró lo registrado y su precio; relaciones familiares entre las personas mencionadas). Para tratar de evitar el pago de derechos se precisaba si los bienes se destinaban al consumo directo, a su uso como insumo productivo, para pagar salarios y, en general, cualquier motivación que fuese distinta a su venta. Cuando no se dice nada sobre el destino del bien se deduce que es su venta o que los motivos por los que se los mueve no pueden ser causa del no pago de derechos a los ojos del declarante. Pero sean puestos en movimiento los bienes con fines mercantiles o no, revelan tratos de ese tipo en las ciudades rioplatenses. En las fuentes procesadas el único vacío observado con regularidad en relación con esta parte de declaraciones es que en algunos casos no se especifica el destinatario. La explicación que encuentro es que esa información estaba en manos del transportista y que a la Aduana en principio le era indiferente quién recibía los bienes, a no ser en los casos en que el declarante informase que los derechos emergentes serían pagados por el destinatario.

En la segunda parte de la fuente se presentaba el listado de bienes relacionados con el movimiento anunciado. La riqueza de las informaciones sobre los bienes es muy dispar. Sobre todo en el tema de las calidades y el origen, sin dudas porque se relacionan directamente con el valor de aforo con el que se los tasaría para el cálculo de los derechos ${ }^{8}$. Seguramente, el declarante dejaba librado al amor al Real Servicio por parte del vista de aduana que realmente abriera los fardos para verificar la declaración, aplicase los aforos ajustados al contenido y se percibieran los derechos que correspondiesen ${ }^{9}$.

Sobre ese documento se observa la intervención de distintas manos. Son las de los servidores reales concernidos por el contenido declarado y en función de establecer si se deben percibir derechos o no y si es el caso, aforar, calcular las sumas devengadas, consignar su pago o promesa de pago y bajo qué condiciones. De estas operaciones, cada servidor de la corona recoge la información que le

\footnotetext{
Plata: metodología e interpretación sobre su evolución en la etapa virreinal (1772-1810)". Folia Histórica del Nordeste, 26, 2016, pp. 74-94.

${ }^{8}$ V. las tablas arancelarias contenidas, p.e. en el Reglamento de 1778.

${ }^{9}$ En el caso de las visitas (inspecciones) a los navíos del comercio ultramarino se pudo proponer sobre la base de algunos indicios que los Oficiales Reales encargados de realizarlas tal vez no descendían a las bodegas con el registro del navío en la mano para, entre ratas y hedores, verificasen el contenido de los contenedores. F. Jumar, "El comercio ultramarino por el complejo portuario rioplatense y l economía regional, 1714-1778”. Magallánica. Revista e Historia Moderna, 3, 5, 2016, pp. 171-259, nota 6, p. 176.
} 
compete para registrarla en los libros particulares por ramo y los libros mayores, base a su vez de las informaciones agregadas y sintetizadas que terminan en las cartas-cuenta que se elevan al Tribunal de Cuentas.

El conjunto de informaciones permite pensar en tres grandes series de análisis, íntimamente relacionados entre sí. En primer término, unos relacionados con la configuración y extensión de los circuitos anudados en Buenos Aires, así como con la intensidad y densidad de las relaciones observadas durante el período considerado. En segundo lugar, análisis en relación con los actores intervinientes. Finalmente, en tercer lugar, la observación de los bienes puede dar informaciones sobre las sociedades que los consumen o los utilizan como insumo productivo.

\section{2.- El procesamiento de los datos y su explotación}

El procesamiento de los datos y su explotación se realizó a través de una aplicación informática especialmente diseñada al efecto, RegAduAR (Registros de Aduana de Antiguo Régimen), diseñada en colaboración con Alejandro Zurdo (a quien nunca terminaré de agradecer) y enteramente codificada por él ad honorem $^{10}$. Respetando la estructura de la información ofrecida por la fuente, el módulo de carga se compone de tres conjuntos de datos: a) datos nominales (imagen 1); b) bienes concernidos (imagen 2) y derechos aplicados (imagen 3). Sería demasiado extenso presentar aquí todas las funcionalidades del programa en relación a cada módulo. Las imágenes 1 a 3 permiten que el lector perciba las opciones que abre a la hora de combinar los datos.

El software no sólo permite cargar la información de modo sistematizado, sino que además $-\mathrm{y}$ sobre todo- tiene un potente generador de consultas que torna cada campo visible en las imágenes 1 a 3 en variable de búsqueda individual o combinada del modo que se desee con una o más de las otras variables. Las imágenes 4 y 5 muestran, la primera, el armado de una consulta muy simple relacionada con los textiles al corte (para saber según la fibra cuántas varas fueron remitidas en función de los espacios señalados) y la segunda el resultado, que exportado a Microsoft Excel® permite trabajar los datos para su presentación.

Imagen 1. Módulo de carga de datos identificatorios de las notas de aduana

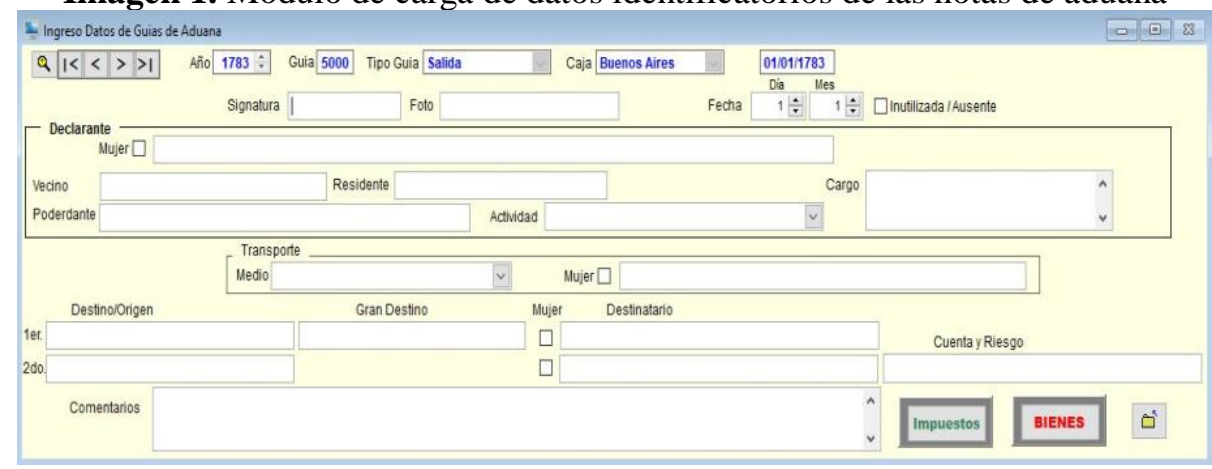

\footnotetext{
${ }^{10}$ Registros de Aduana de Antiguo Régimen. Base de datos marzo de 1779 a diciembre de 1783 recopilada a partir de las notas de aduana registradas en la Aduana de Buenos Aires, Archivo General de la Nación, Argentina, XIII-14-9-1; 14-9-5; 33-11-2; 33-11-3; 34-1-5; 34-2-1; 34-2-5; 34-3-1; 34-4-1; 34-4-2; 34-1-5. En adelante: RegAduAR, base 1779-1783.
} 
Imagen 2: Módulo de carga de datos relacionados con los bienes concernidos

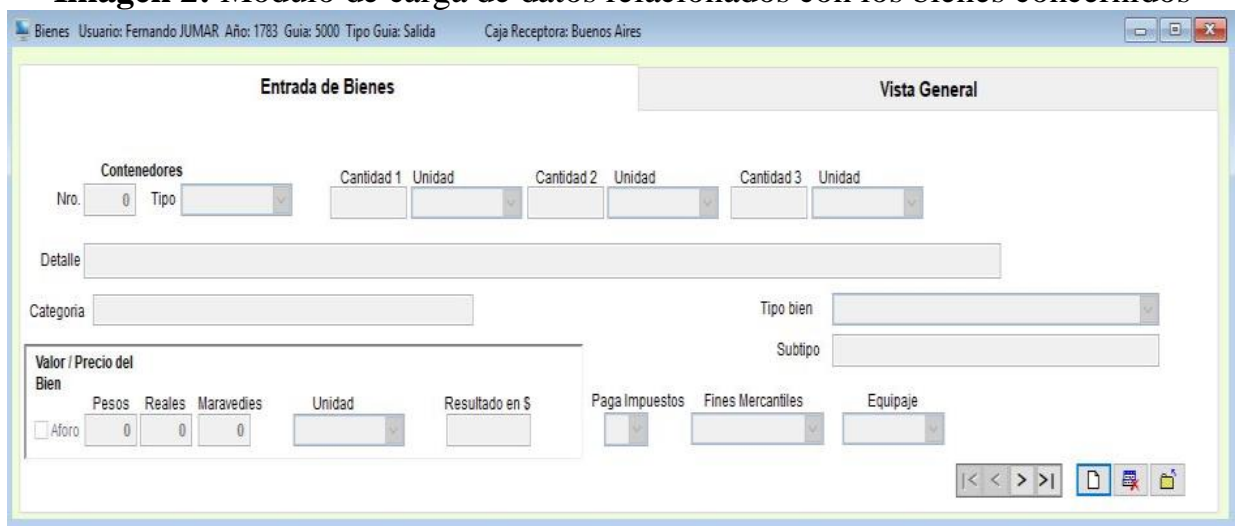

Imagen 3: Módulo de carga de datos relacionados con los derechos reales percibidos

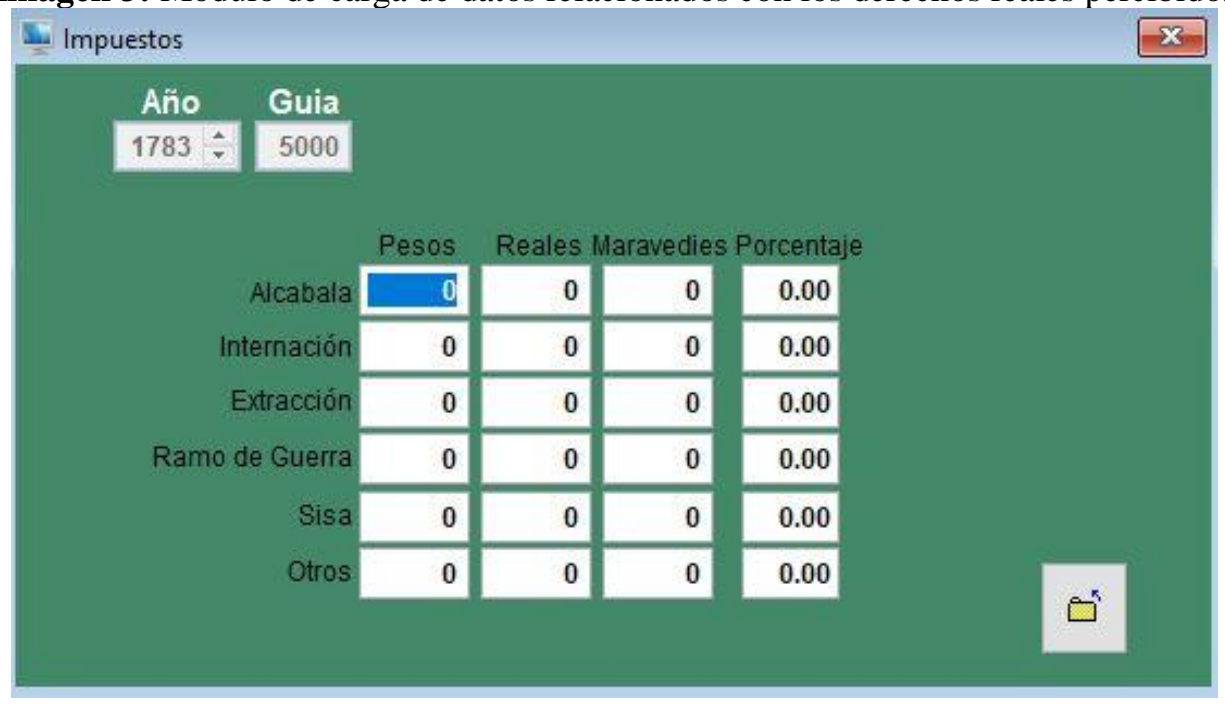

Imagen 4. Módulo de consultas

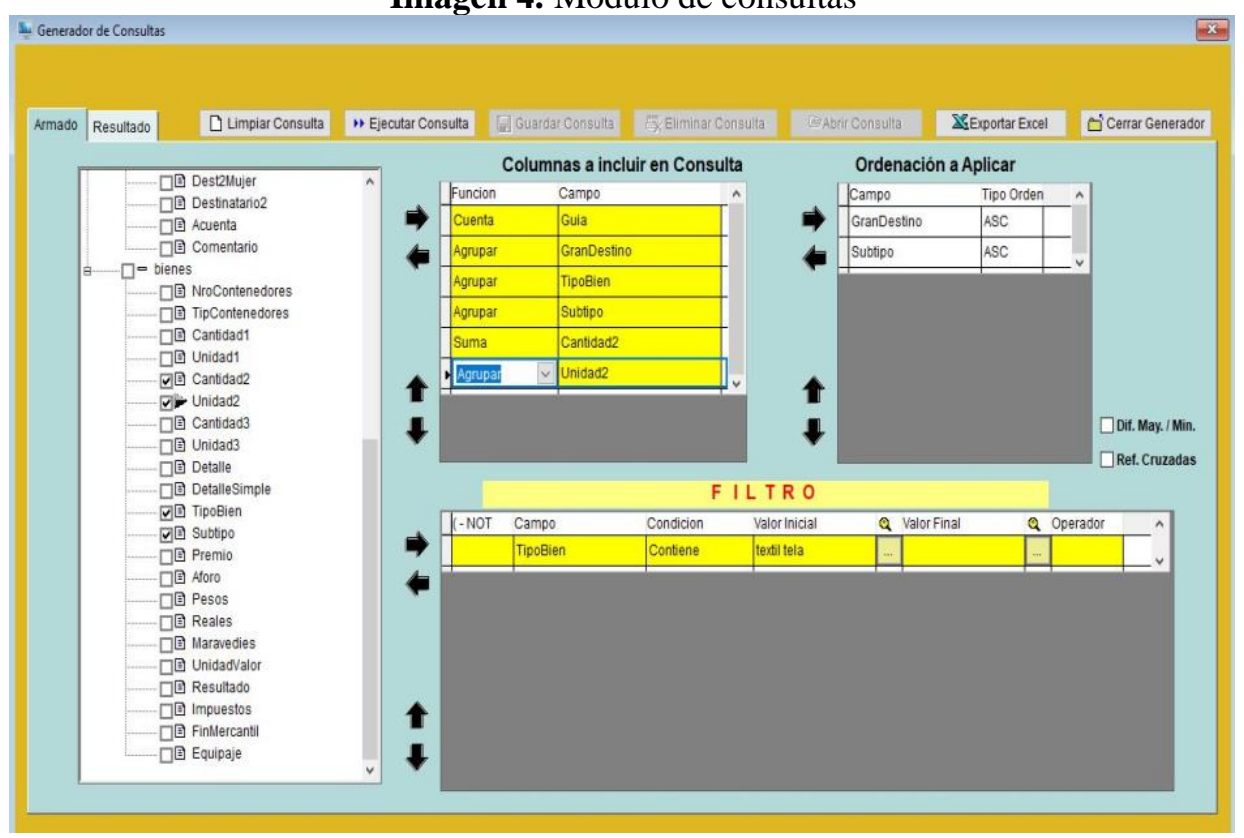


Imagen 5. Resultado de una consulta

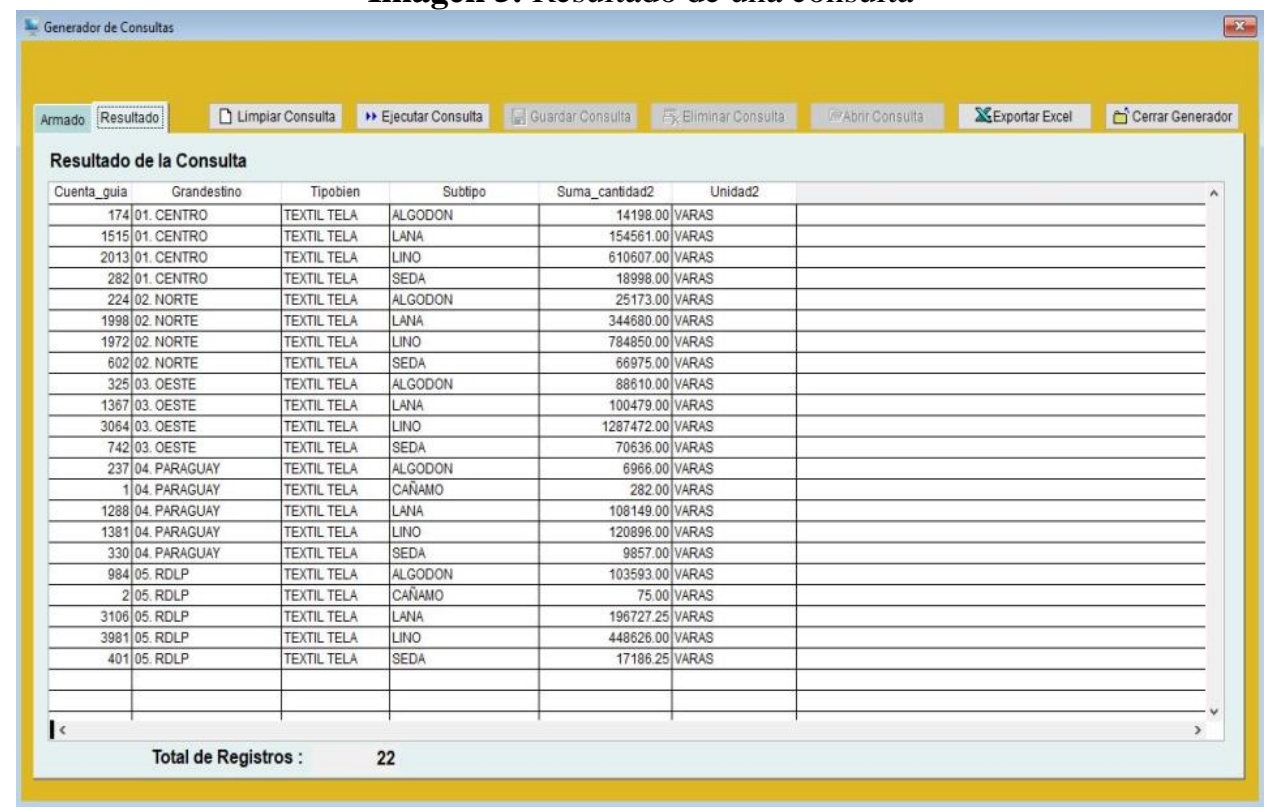

El hecho de que RegAduAR simplifique en grado sumo la tarea de carga y explotación de la información libera energía para que el investigador se concentre en los grandes desafíos metodológicos que conlleva la preparación de la información para su explotación. A saber, la uniformización de criterios para el proceso de carga y depuración/homogeneización y la metrología. Aunque el software tiene previstas rutinas de homogeneización, si no se establecen y respetan desde el comienzo algunos criterios de uniformización de la carga de datos, tanto en lo relacionado con los bienes ${ }^{11}$ como con las personas ${ }^{12}$, la explotación final de los datos se vería comprometida.

Varias personas intervinieron en la primera carga de datos que se prolongó entre 2009 y $2015^{13}$. En 2016-2018 verifiqué por completo los datos contrastando con las fotografías de las fuentes, al tiempo que se procedió a las tareas de depuración y homogeneización para tornar los datos explotables. En el proceso se impuso la

\footnotetext{
${ }^{11}$ P. e. Dadas las características del generador de consultas, no importa demasiado si en una nota un bien es "bretaña legítima de tercera" y en otra "bretaña de tercera legítima", y se los carga siguiendo el orden de las palabras que está en las fuentes. Sí generaría problemas si no se decide bajo qué denominación unificar "pontobi", "puntibi”, "puntivi" o "tucuyo" y "tocuyo". Otra serie de problemas emergen si no se conoce los bienes que se van detectando para incluirlos a medida que se van cargando en alguna de las categorías y subcategorías que se hayan establecido en función de la observación deseada (p.e. saber la fibra en que están hechos los textiles para ir asignándolos como pertenecientes a 'algodón', 'lino', 'lana', 'seda', 'cáñamo', 'pita' que son las presentes en los circuitos observados. Al establecerse esas categorías se decidió perder de vista las mezclas y que se atribuirían los textiles en función de la fibra dominante, ya que del análisis de las fuentes se dedujo que era el criterio de las autoridades para percibir derechos.

12 P.e. Sabiendo que la ortografía del castellano no estaba consolidada, se decidió modernizarla en todos los casos siguiendo criterios unificados pero eliminando los acentos para reducir errores de tipeo. Siempre en toda decisión metodológica hay posibles pérdidas, como la derivada de que todos los "Pérez" y "Peres" se convierten en "Perez" (sin tilde y con z), mientras el declarante no tenga nombre de pila portugués. Pero si algún "Francisco Peres" era portugués, se perderá la posibilidad de identificarlo como tal por su nombre, si en la fuente no hay otros datos que permitan saberlo.

${ }^{13}$ La primera carga de datos fue realizada por: Maximiliano Acebal (marzo de 1779); Nicolás Biangardi (abril a septiembre de 1782); Ricardo Bogosian (enero, febrero y septiembre de 1781); José Bozzo (octubre y noviembre de 1780; noviembre de 1781); María Claudia Errecart (agosto, septiembre y noviembre de 1779; febrero, abril, y diciembre de 1780; marzo a julio, octubre y diciembre de 1781; enero, febrero, marzo, octubre, noviembre y diciembre de 1782; enero, abril y junio de 1783); María Luz Jardón (enero y marzo de 1780); Fernando Jumar (mayo, julio, agosto a diciembre de 1783); Roberto Querzoli (mayo a agosto de 1780; agosto de 1781; febrero y marzo de 1783); María Emilia Sandrín (abril de 1779; septiembre de 1780); José Sovarzo (mayo, junio, julio, octubre y diciembre de 1779). La verificación, depuración, homogeneización y categorización de los datos estuvo a cargo de Fernando Jumar.
} 
necesidad de descartar paneles enteros de información y volver a cargarlos. La depuración y homogeneización implicó diversas exploraciones para comprender ciertos bienes o encontrar formas de reducir la presentación y la metrología a comunes denominadores dentro de la misma especie de bienes. ${ }^{14}$ Tras todos esos controles se piensa haber llegado a tener algunos buenos datos. Quedan series de información por depurar y homogeneizar (las relacionadas con los transportes y los transportistas, la unificación de varios bienes) y, sobre todo, dar precios a las cosas.

\section{3.- La representatividad de los datos}

Se interroga la representatividad de los datos obtenidos en función: a) de su construcción; b) del período; c) del fraude (sub-registro dentro del circuito legal) y el contrabando puro (comercio directo).

\section{La construcción de los datos}

El hecho de trabajar con piezas documentales elaboradas por 5.962 declarantes hace abandonar toda ilusión de manejar cualquier tipo de información sistematizada en la fuente, más allá de la estructura de la información que debía estar presente en cada nota de aduana. De allí que la forma de presentación de cada ítem y la metrología, depende a veces hasta del origen regional del declarante. Una de las tareas de unificación y depuración ya aludidas consistió en superar esta limitación y reducir la presentación de las informaciones en la fuente a comunes denominadores para que emerjan las series buscadas.

La Tabla 1 del trabajo al cual complementa el presente ${ }^{15}$ incluye, sólo por categoría y sub-categoría, la distribución de los 112.790 registros de bienes, pero sin llegar al grado del detalle porque significaría reproducir toda la base de datos. De un modo u otro se intervino en cada registro asimilando lo declarado a los comunes denominadores establecidos, a veces emergentes de mini investigaciones ${ }^{16}$ (y no tan mini para los textiles) dedicadas a muchos bienes desde para saber simplemente de qué se trataba hasta para precisar detalles sobre calidades ${ }^{17} \mathrm{y}$, sobre todo, la metrología.

En relación con la metrología, se recogió todo dato al respecto de la bibliografía que goza de mayor aceptación. El mayor o menor grado de precisión cede ante la posibilidad de integrar las observaciones con posterioridad. Así, por ejemplo, está establecido que la historiografía toma por buenas las 7 @ que formalmente contenía cada zurrón de yerba. En otros casos, se recogieron equivalencias

\footnotetext{
${ }^{14}$ En las notas cada persona presenta una lista de bienes descritos como los conocía y en las unidades de medida que manejaba.

${ }^{15}$ F. Jumar, "Hay para todos"

${ }^{16}$ Gracias a Internet se pudieron hacer búsquedas en las ediciones del Diccionario de la Real Academia, diversos diccionarios antiguos especializados, guías de comerciantes, descripciones regionales con sus producciones, muestrarios conservados en archivos, tablas arancelarias, museos especializados y especializadísimos, portales de internet creados por apasionados de los más diversos temas que rezuman conocimiento íntimo sobre lo tratado y notable erudición, etc.

${ }^{17}$ Es un buen momento para agradecer muy particularmente Gloria Deluca, más conocida como Coca Jumar, modista casi nonagenaria retirada, que sin que me diera cuenta desde la más tierna infancia me introdujo en el mundo de las telas y sus usos. También a Claudia Porcellana, especialista en temas de conservación patrimonial, por su ayuda en la identificación de los textiles. Finalmente, a los comerciantes y empleados casas de venta de telas, mercerías, ferreterías y antigüedades por su siempre buena predisposición para satisfacer mis consultas.
} 
contenidas en los documentos ${ }^{18}$. Finalmente, fueron de utilidad los libros de caja de una compañía mercantil abordados para otros fines en curso de ruta $^{19}$ y la multiplicidad de vías que ofrece Internet.

\section{4.- El período 1779-1783}

El inicio de la serie de datos lo impone el de la fuente principal, las notas de aduana, cuya elaboración se dispone junto con la de la creación de la Aduana de Buenos Aires (1778), que de modo efectivo comenzó a funcionar en marzo de 1779 , aunque en enero y febrero de ese año se despacharon guías de aduana que no se han encontrado ${ }^{20}$. Cerrar la observación en diciembre de 1783 ofrecía como ventaja mantener la clásica unidad de análisis quinquenal y permite ver los mercados terminando de salir de la guerra y entrando en un ciclo de paz, que parecía durable ${ }^{21}$.

Entre medio, se ponderaron dos juegos de variables. A) Los embates de la monarquía administrativa por avanzar sobre los territorios englobados en la observación; b) La doble coyuntura conflictiva que estalla apenas se quieren comenzar a concretar esos embates: la guerra anglo-española de 1779-1783 y las rebeliones altoperuanas de 1780-1781. En ambos casos, la crítica se orientó a tratar de establecer qué significan los datos obtenidos en función de la historia regional desde la invasión europea hasta la crisis de la Monarquía y de la capacidad de control sobre la circulación.

\section{5.- El avance de la monarquía administrativa}

El período se enmarca de lleno en lo que la historiografía tradicionalmente llama las 'reformas borbónicas'22. El trabajo de síntesis más reciente desde la perspectiva clásica que aborda el impacto de esas reformas en los espacios bajo

\footnotetext{
${ }^{18} \mathrm{P}$. e. en los textiles, en algunas notas se declaran cuántas piezas de determinada tela se registran y se dice cuántas varas suman en total. De allí ha sido simple establecer medianas y extrapolarlas a las piezas sin descripción del vareaje.

${ }^{19}$ Archivo Histórico de la Provincia de Buenos Aires (Argentina), 7-4-6-6, "Libro de compras de los géneros que se compran (sic, tachado en original) perteneciente a don Marcelino Callexas Sanz y don Ramón García Pérez desde 21 de octubre de 1780"; 7-5-6-5, "Libro de caja perteneciente a dn Marcelino Callexas Sanz y dn Ramón García Pérez, y da principio en 6 de noviembre de 1780. Libor primero". Sobre el caso, v. Fernando Jumar, “«Buscar la vida» en el Río de la Plata. Marcelino Callexas Sanz, 1757-1820". Illes i Imperis, 18, 2016, pp. 44-76.

${ }^{20}$ En el AGN no se han localizado las notas para los meses de marzo a diciembre de 1779 y la información se tomó de los libros particulares que las registraban una vez transformadas en guías. Algo que no se ha podido explicar es que el primer libro de la serie se inicia en el mes de marzo, lo que no asombra ya que por otras fuentes se sabe que es cuando se instala efectivamente la Aduana. Pero la numeración de las guías arranca con la 466. Es decir, que al parecer en enero y febrero de 1779 se despacharon 465 guías sobre las que no hay rastros. AGN, XIII-14-9-1, "1 Libro Real particular donde se asientan las Guías de referencia, en que se despachan por esta Real Aduana todos los Géneros, y Frutos, así de España como Extranjeros, y del País para las Provincias interiores del Reyno, Montevideo, y demás Puestos de la otra Banda de este Río; igualmente, que para los Registros que regresan a España, y cuyas partidas van numeradas, como las mismas Guías desde el Número 466, en adelante sin interpolación...".

${ }^{21}$ En los negocios, no sólo es importante la formalidad de la paz. También ocupa un lugar destacado la convicción de que será duradera, dentro de lo razonable, porque los actores sabían que guerras siempre hay, y sólo los menos avezados no operaban en contextos de paz y de guerra, adaptando las estrategias. Un estudio centrado en una comunidad mercantil bretona entre mediados del siglo XVII y comienzos del siguiente resalta los aspectos mencionados para engarzar las actividades que ve desplegar a sus actores que articulan el comercio legal del mar del Norte y del Báltico, con la pesca del bacalao en Terranova y el comercio legal e ilegal con el complejo portuario andaluz o Lisboa en tiempos de paz y el comercio directo con donde se pudiera en tiempos de guerra. André Lespagnol, Messieurs de Saint-Malo, une élite négociante au temps de Louis XIV, 2 Tomos, Rennes, Presses Universitaires de Rennes, 1997.

22 V. el dossier publicado en la revista Historia Caribe (11, 29, 2016, http://investigaciones.uniatlantico.edu.co/revistas/index.php/Historia_Caribe/issue/view/116 en el que tres textos analizan la construcción de la categoría analítica 'reformas borbónicas' asociada a la creación de las historias nacionales decimonónicas para la Nueva España, Nueva Granada y Río de la Plata y un cuarto trabajo lo hace para las 'reformas pombalinas' en el mundo luso.
} 
observación incluye los años 1779-1783 en una tendencia general de crecimiento económico y señala como mayor perturbación el ciclo de guerras abierto en $1796^{23}$. En términos generales, toda la bibliografía consultada reserva las peores consecuencias para el comercio en la segunda mitad del siglo XVIII al último ciclo aludido, que además es el que engarza con el de las independencias americanas.

El período virreinal rioplatense cuenta con numerosas investigaciones. Para el establecimiento de los contornos generales, operan en mí los grandes clásicos, cornucopias de información de indudable calidad y problematizaciones. También se recurre a bibliografía especializada. El comercio ultramarino durante el período virreinal cuenta con importantes estudios ${ }^{24}$, siendo los más recientes que conozco de Maximiliano Camarda ${ }^{25}$ y de Fabrício Prado ${ }^{26}$. El tráfico en los mercados interiores americanos vinculados con Río de la Plata ha recibido mucha atención, sobre todo en los años 1980-1990. En general son investigaciones emparentadas de cerca o de lejos con las de Carlos Sempat Assadourian ${ }^{27}$. Si bien hay mucha información procedente de fuentes fiscales que son derivadas de las notas de aduana, desgraciadamente pocas veces coinciden los períodos abordados por las investigaciones o la organización espacial de la información, lo que complica la tarea de cruce articulado de datos y explicaciones. Es un trabajo denso para el que se necesita primero cumplir con el armado de la imagen que emerge de los datos obtenidos y formular hipótesis en función del punto de vista adoptado ${ }^{28}$. Un paso posterior será integrar la información en la ya existente para refinar las observaciones y reformular las hipótesis en lo que fuese necesario.

En función de los intereses actuales, se señala que, hacia marzo de 1779, cuando comienza la serie de datos, el Virreinato del Río de la Plata está comenzando a existir más allá de los papeles y se puede esperar que los circuitos acusen el doble impacto de las medidas particulares tomadas por el primer virrey y las generales tomadas por la Corona en relación al comercio. El segundo virrey, Vértiz (06/1778-03/1784), se ocupó de intentar poner en práctica lo planeado en una coyuntura compleja.

\footnotetext{
${ }^{23}$ Jorge Gelman; María Inés Moraes, "Las reformas borbónicas y las economías rioplatenses: cambio y continuidad”, en Jorge Gelman; Enrique Llopis; Carlos Marichal (Coords.), Iberoamérica y España antes de las independencias, 1700-1820: crecimiento, reformas y crisis, México, Instituto de Investigaciones "Dr. José María Luis Mora", 2014, pp. 31-74.

${ }^{24}$ Hernán Silva y Arturo Bentancur publicaron muchos y valiosos textos. Entre ellos: Hernán Asdrúbal Silva, "Consideraciones sobre el comercio ilícito en el Río de la Plata", en Cuadernos del Sur, Universidad Nacional del Sur, Bahía Blanca (Argentina), 17, 1984, pp. 101-116; "Hamburgo y el Río de la Plata. Vinculaciones económicas a fines de la época colonial”, en Jahrbuch für Geschichte von Stäat, Wirtschaft und Gesellschaft Lateinamerikas, 21, 1984, pp. 189-209; "La estructuración del comercio y la navegación desde el Río de la Plata a Cuba", en Anuario de Estudios Americanos, 51, 2, 1994, pp. 61-73; El comercio entre España y el Río de la Plata (1778-1810), Madrid, Banco de España, 1993. Arturo Ariel Bentancur, "La provisión de servicios en el puerto colonial de Montevideo: alcances y limitaciones de una fuente local de riqueza", en Anuarios de Estudios Americanos, 53, 2, 1996, pp. 123-145; El puerto colonial de Montevideo, 2 tomos, Montevideo, Facultad de Humanidades y Ciencias de la Educación, 1997-1998; "Buenos Aires y Montevideo coloniales: entre la comunidad y la controversia”, en Silva, Hernán A. (Dir.), Los caminos del Mercosur. Historia económica regional. Etapa colonial, México, Instituto Panamericano de Geografía e Historia, 2004, pp. 427-448.

${ }^{25}$ Maximiliano Camarda, "La Región Río de la Plata y el comercio ultramarino durante las últimas décadas del siglo XVIII: circulación comercial, mercancías y actores”, Tesis de doctorado inédita, Universidad Nacional de La Plata, 2015.

${ }^{26}$ Fabrício Prado, Edge of Empire. Atlantic network and revolution in Bourbon Río de la Plata, Oakland (California, EEUU), University of California Press, 2015.

${ }^{27}$ El grueso de esa bibliografía producida hasta 2011 ha sido reseñada en Fernando Jumar, "El espacio colonial peruano en la historiografía sobre circulación mercantil", en História Ecônomica \& História de Empresas, 17, 2, 2014, pp. 475-534.

${ }^{28}$ F. Jumar, "Hay para todos".
} 
Hay muchas novedades. El primer virrey, Pedro de Cevallos, emite en 1777 una serie de medidas que crean un mercado virreinal con sus adentros y afueras claramente delimitados ${ }^{29}$. Los mayores cambios son para los mercados altoperuanos. Hasta entonces, miraban formalmente hacia Lima, ahora se los obliga a hacerlo hacia Buenos Aires. Pero Alto Perú es un gran consumidor y mantuvo sus tratos con el Bajo Perú, como antes los mantenía con los circuitos del sur y con todo otro circuito que le proveyera lo necesario para seguir produciendo plata ${ }^{30}$. El balance final del intento de polarización del Alto Perú hacia Río de la Plata es un rotundo fracaso. Cuando llegue la crisis de la Monarquía, se ve que no hay el mismo grado de integración entre las oligarquías comarcales al sur de Charcas que entre éstas y las altoperuanas ${ }^{31}$.

Los mercados al sur de Charcas hacía tiempo que estaban polarizados en dirección del Atlántico a través de Río de la Plata, pero por flujos económicos más que por decisiones políticas y aún en contra de algunas de ellas ${ }^{32}$. Desde el temprano siglo XVII se establecen contactos a través de los Andes con Chile y el Bajo Perú por el Pacífico ${ }^{33}$ y, desde antes de la creación de la ceca de Santiago $\left(1749^{34}\right)$, se ve crecer la presencia de oro en proveniencia de Chile en las remisiones a Europa por el complejo portuario rioplatense ${ }^{35}$. En cuanto a los contactos con Paraguay, alcanza recordar que Buenos Aires fue fundada por criollos asuncenos en 1580 y el trabajo de J. C. Garavaglia sobre la yerba mate ${ }^{36}$.

Desde 1622 hasta 1777 las licencias de comercio ultramarino con destino en el complejo portuario rioplatense permiten de modo sistemático los tratos con las gobernaciones de Buenos Aires, Tucumán y Paraguay. Las excepciones que permiten llegar hasta los mercados altoperuanos son numerosas, usualmente derivadas de la necesidad de servicios puntuales por parte de la Corona. La

\footnotetext{
${ }^{29}$ V. Enrique M. Barba, Don Pedro de Cevallos. Gobernador de Buenos Aires y virrey del Río de la Plata, La Plata, Facultad de Humanidades y Ciencias de la Educación, 1937. Emilio Ravignani, "El Virreinato del Río de la Plata (1776-1810)", en Ricardo Levene (Dir. gral.), Historia de la Nación Argentina (Desde los orígenes hasta la organización definitiva en 1862), Tomo IV, $1^{\text {a }}$ sección, $1^{\text {a }}$ edición 1940, Buenos Aires, El Ateneo, 1961, pp. 11-195. Sergio Villalobos, "La política comercial del virrey Cevallos y la reacción chileno-peruana”, en Trabajos y Comunicaciones, 11, 1963, pp. 163-177. Guillermo Céspedes del Castillo, "Lima y Buenos Aires. Repercusiones económicas y políticas de la creación del virreinato del Plata", en Anuario de Estudios Americanos, 3, 1946, pp. 667-874.

${ }^{30}$ Así como antes el Alto Perú tenía tratos legales (por vía de excepción relativamente frecuente) e ilegales con las provincias de abajo, tras 1777 no se quiebran las conexiones con lo que quedó del virreinato peruano. V.p. e. Alicia Polvarini de Reyes, "Mercado interno y región Moquegua y las rutas del aguardiente de uva en los siglos XVIII y XIX", en Margarita Guerra Martinière, Cristina Mazzeo de Vivó, Denisse Rouillon Almeida (Eds.), Historias compartidas: economía, sociedad y poder, siglos XVI-XX: actas del primer encuentro de historia Perú-Argentina, Lima, PUCP/Instituto Riva-Agüero, 2007, p. 455-491.

${ }^{31}$ José Luis Roca, Ni con Lima ni con Buenos Aires. La formación de un Estado nacional en Charcas, La Paz, Ed. Plural/IFEA, 2007.

${ }^{32}$ Fernando Jumar, Le commerce atlantique au Río de la Plata, 1680-1778, 2da. ed. Aumentada, $1^{\text {a }}$ ed. Electrónica, La Plata, UNLP, 2010, http://www.memoria.fahce.unlp.edu.ar/tesis/te.364/te.364.pdf (consulta 14/08/2018).

${ }^{33}$ P. e. ya en el temprano siglo XVII se encuentran relativamente importantes operaciones de crédito entre Buenos Aires y Santiago de Chile. V. Martín L. E. Wasserman, "Más allá de las redes: deudas y contratos en Buenos Aires durante el temprano siglo XVII", Tesis de Maestría inédita, Universidad de San Andrés, 2009; "Las prácticas crediticias en Buenos Aires durante el siglo XVII. Instrumentos, contextos relacionales e instituciones en una sociedad emergente", 2 tomos, Tesis de Doctorado, Universidad de Buenos Aires, 2014; existe una versión publicada: Las obligaciones fundamentales. Crédito y consolidación económica durante el surgimiento de Buenos Aires, Buenos Aires, Prometeo Libros, 2018.

${ }^{34}$ No sólo salía oro chileno por el complejo portuario rioplatense. En Chile también había minas de plata. Para mediados del siglo XVIII "comenzaba a producirse plata en grandes cantidades" que también pasaba por la ceca de Santiago. Pedro Damián Cano Borrego, "La Casa de Moneda de Santiago de Chile en el siglo XVIII", en Anuario. Asociación Numismática de Chile, 2010-2017, pp. 30-42.

${ }^{35}$ Fernando Jumar, "El comercio ultramarino por el complejo portuario rioplatense y la economía regional, 1714-1778”, en Magallánica. Revista de Historia Moderna, 3, 5, 2016, pp. 171-259.

${ }^{36}$ Juan Carlos Garavaglia, Mercado interno y economía colonial (Tres siglos de historia de la yerba mate), México, Grijalbo, 1983.
} 
circulación en dirección del Corregimiento de Cuyo (integrado políticamente a Chile hasta 1776) y a través de él con Chile y con las costas del Pacífico sur se da en un vacío legal que nadie se preocupa en llenar, la ruta existe y se perciben derechos, de modo que su institucionalización es informal desde antiguo.

Por vía fluvio-marítima, Buenos Aires se inserta en los circuitos ultramarinos dentro de la Monarquía. Entre 1588 y 1618 se permitieron los tratos con el Brasil, al calor de la unión de coronas. En 1622 se abre una ruta de comercio legal ultramarino con Río de la Plata que completa el esquema de flotas y galeones. Los registros de Buenos Aires no son el Galeón de Manila, pero tienen su lugar en el esquema general y sobre todo desde temprano vinculan directamente la región con el centro de la gracia y de los negocios ${ }^{37}$. La Corte, el Consejo de Indias, la Contratación, el Consulado de Sevilla primero y el de Cádiz después están más cerca de Buenos Aires que Lima. También el río es visitado por navíos de los circuitos inglés, portugués y francés por dentro del circuito legal por medio de licencias especiales (por momentos asociadas a la trata de esclavizados ${ }^{38}$ ), o por fuera mediante el comercio directo ${ }^{39}$.

Los años de la Guerra de Sucesión son de gran crecimiento para la economía regional ${ }^{40}$ y se terminan de consolidar las relaciones con los mercados interiores. Con posterioridad, y a la sombra de las idas y venidas de Colonia del Sacramento entre españoles y portugueses ${ }^{41}$, la economía regional sigue creciendo lo mismo que el comercio ultramarino. Las cifras del circuito legal portugués son desesperadamente fragmentarias, con lo que se tiene una visión parcial e incompleta del tráfico ultramarino del complejo portuario rioplatense entre 1716 y 1777. Dentro del circuito español, Río de la Plata escapa un poco antes que otros al exclusivismo gaditano, desde que en 1768 se abre una ruta con La Coruña para las fragatas-correo que también son vehículo de actividades mercantiles ${ }^{42}$. En términos generales, hay que tener presente que se está ante mercados comparativamente pequeños y que, por ejemplo, el total de caudales registrados legalmente por el circuito español entre 1714 y $1778^{43}$ apenas equipara los de una buena flota de la Nueva España.

\footnotetext{
${ }^{37}$ Desde 1612 Buenos Aires mantiene de modo intermitente un diputado ante la Corte (y frecuentemente cubriendo los gastos con la parte que le cabe al Cabildo del negocio de los cueros). En el siglo XVIII uno de esos diputados, Domingo de Marcoleta actuó durante varios años y forma parte de los "ilustrados españoles". En la ausencia de la convocatoria a Cortes y por más que las ciudades americanas no habrían sido convocadas a ellas, Buenos Aires (y otras ciudades americanas sin duda) recurren al mismo mecanismo que las ciudades que sí habrían formado parte de las Cortes para negociar de modo directo sus asuntos.

${ }^{38}$ En el siglo XVII es el turno de compañías portuguesas, entre 1701-1715 de la franco-española Compagnie de Guinée et de l'Assiento, entre 1715 y 1738 (con interrupciones) de la South Sea Company. Desde 1748 la trata se lleva adelante por empresas al menos formalmente españolas.

${ }^{39}$ José Torre Revello, "Los Navíos de Registro en el Río de la Plata. 1500-1700", en Boletín de la Academia Nacional de la Historia (Argentina), 34, Buenos Aires, 1963, pp. 529-559; "Un contrabandista del siglo XVII en el Río de la Plata", en Revista de Historia de América, Instituto Pan-Americano de Geografía e Historia, Comisión de Historia, México, 1958, pp. 121-130. Zacarías Moutoukias, Contrabando y control colonial en el siglo XVII, Buenos Aires, CEAL, 1988.

${ }^{40}$ Fernando Jumar, "El primer boom de la exportación de cueros y la sociedad local. Río de la Plata. Fines del siglo XVII, comienzos del siglo XVIII", en XXI Jornadas de Historia Económica, Asociación Argentina de Historia Económica/Universidad Nacional de Tres de Febrero, Caseros, 2008; "El precio de la fidelidad. La Guerra de Sucesión en el Río de la Plata, los intereses locales y el campo Borbón”, en Annie Molinié; Alexandra Merle (Dirs.), L'Espagne et ses guerres. De la fin de la Reconquête aux guerres de l'Indépendance, París, Presses de l'Université Paris/Sorbonne, 2004, pp. 203-236.

${ }^{41}$ F. Jumar, Le commerce atlantique. Fabrício Prado, A Colônia do Sacramento: o extremo sul da América portuguesa no século XVIII, Porto Alegre, F. P. Prado, 2002. Paulo Possamai, Colonia del Sacramento. Vida cotidiana durante la ocupación portuguesa, Montevideo, Torre del Vigía Ediciones, s/f [post. 2007].

${ }^{42}$ Manuel Lelo Belloto, Correio Marítimo hispano-americano. A carreia de Buenos Aires (1767-1779), Assis (Brasil), Universidade de Assis, 1971.

${ }^{43}$ En distintas especies de oro y plata, y por cuenta de particulares, el clero y la Real Hacienda se registraron 50.845.969 pesos de a 8. V. F. Jumar, "El comercio ultramarino", Cuadro 1, p. 195.
} 
Río de la Plata nunca quedó incomunicado con los circuitos ultramarinos y a veces asombra la velocidad con la que llegan ciertas informaciones. Aún durante las guerras, se abrían canales legales de tratos que ponían en suspenso de modo parcial el monopolio y tras los cuales se practicaba el comercio directo, pero esos canales también vehiculizan el comercio legal y la circulación de informaciones. Maximiliano Camarda muestra en las vías de sustitución legal que se montaban al circuito legal español en los tiempos convulsos y concluye que gracias a ellas el impacto de las guerras atlánticas es menor que el esperable ${ }^{44}$.

Como consecuencia de la expulsión de los portugueses, el tráfico mayor se concentra en el circuito español. Formalmente, tras 1777 por primera vez en mucho tiempo el río de la Plata es un río interior español y el contrabando (hay evidencias del tráfico de embarcaciones pequeñas y medianas llegadas desde Brasil) retoma viejas prácticas del río (las arribadas forzosas maliciosas). El Reglamento de libre comercio de octubre de 1778 confirma disposiciones para la región de febrero de ese año. La novedad es que hay más puertos interlocutores en España, pero la navegación mediante navíos sueltos se practica desde 1622 y el cambio mayor es de 1720 cuando se dispone que la carrera de Buenos Aires ya no se concedería en exclusividad a nadie ${ }^{45}$ y estaba abierta a quien quisiera practicarla desde Cádiz. Ello aumenta la cantidad de interlocutores posibles presentes en el complejo portuario rioplatense al mismo tiempo que compiten entre sí y aumenta el número de migrantes vinculados a la actividad. Se complejiza la plaza mercantil y en el plano institucional, en 1748 se advierte el nacimiento de un sector de individuos que se identifican como "del comercio" e inician un proceso de corporativización que termina en la creación del Consulado de Buenos Aires en $1794^{46}$.

Al comenzar el último cuarto del siglo XVIII confluyen en un punto varios procesos que se traducen en un conjunto de medidas que parecen dibujar un plan, pero no lo son. Son resultado de negociaciones en múltiples frentes, dentro de la Monarquía y fuera de ella. Las intenciones inmediatas de la Corona están guiadas por el objetivo de poner en pie la Monarquía tras la guerra de los siete años. Lo de La Habana y Manila, no puede volver a pasar. En Río de la Plata ese objetivo se traduce en los conocidos cambios administrativos. Para que se comiencen a concretar hubo que enviar una muy fuerte expedición militar. Y de este modo, el avance de la monarquía administrativa en Río de la Plata empalma con la guerra con Gran Bretaña que todos sabían que se venía ${ }^{47}$.

La expedición de 1776-1777, que puso fin a la presencia portuguesa en la banda norte del río de la Plata hasta tiempos de la revolución, no es ajena al clima de guerra general que se vive desde el inicio de la rebelión de los dominios británicos en América del Norte (1776) y el apoyo apenas velado de los Borbón

\footnotetext{
${ }^{44}$ Maximiliano Camarda, "Algunos datos sobre el comercio ultramarino salido del complejo portuario rioplatense", en $E l$ Taller de la Historia, 12, 2019, pp. 184-207.

${ }^{45}$ Lo más usual: exclusividad de la ruta durante cinco años y para realizar dos viajes compuestos cada uno de dos navíos mercantes y un vivandero.

${ }^{46}$ Javier Kraselsky. "Las estrategias de los actores del Río de la Plata: las Juntas y el Consulado de comercio de Buenos Aires a fines del Antiguo Régimen (1748-1809)", Tesis de doctorado inédita, Universidad Nacional de La Plata, 2011.

${ }^{47}$ En función de la mirada general, conviene tener presente que la guerra anglo-española de 1779-1783 no es el único frente de la Monarquía española, también se hicieron esfuerzos en el Mediterráneo por la misma época. Se hizo una expedición contra Argel en 1775, que tuvo un eco en 1783 y, sobre todo en 1784. Este último año en alianza con Nápoles-Sicilia, Portugal y la Orden de Malta se cerró el problema de los corsarios berberiscos hasta las guerras napoleónicas.
} 
franceses y españoles a la causa republicana desde el comienzo. Solucionar el tema portugués en el sur, en una visión amplia, tiene entre sus ventajas debilitar de modo apenas indirecto la economía británica.

Sin dudas, la exhibición de poder de la Monarquía sirvió de aviso a los rioplatenses. Los cabildos de Buenos Aires y de Montevideo venían resistiendo, con suerte dispar, los avances de la Corona desde los años $1730^{48}$. Por ejemplo, en 1778 se pudo imponer la creación de una aduana en Buenos Aires, que había sido rechazada en 1774 por el Cabildo de la ciudad ${ }^{49}$. Desde 1777 se ve a las corporaciones de comerciantes y de hacendados competir por devenir el interlocutor local privilegiado de la Corona. Lo hacen tratando de ser la más magnánima, que es del modo que más le gusta a la Corona y la cuenta la termina pagando el conjunto de la sociedad ${ }^{50}$.

También, esa expedición, además de todo lo habitualmente señalado, generó inusitados estímulos para la economía regional ${ }^{51}$, como lo había hecho antes por ejemplo- el sitio y bloqueo a Colonia del Sacramento en $1735-1737^{52}$ y durante todo tiempo la presencia en el río de navíos y hombres del rey. Ello se refleja en el punto de partida inicial del consumo regional rioplatense durante el período observado (1779). También hay que tener presente que la perturbación de la navegación mercantil afecta las relaciones interregionales más que las intrarregionales.

Los navíos del servicio real ${ }^{53}$ y los preparativos en función de eventualidades ${ }^{54}$ son buenos sustitutos que mantienen la economía regional en funcionamiento,

\footnotetext{
${ }^{48}$ Durante la Guerra de Sucesión Buenos Aires adhiere tempranamente al bando Borbón y ello le vale obtener vista favorable en varias súplicas que venía tramitando desde los años 1670. Con posterioridad, se observa que cuando Felipe V termina de consolidar la corona en su cabeza a mediados de los años 1720 se vuelve hacia los dominios americanos para recuperar todo lo cedido en el momento de debilidad para obtener préstamos, donativos y sobre todo, la aceptación de su legitimidad. En Río de la Plata ello se traduce en la forma en que se funda Montevideo (Buenos Aires quería un pago dependiente de su cabildo, la Corona crea una ciudad que quita parte del territorio de la banda norte de la jurisdicción de la Buenos Aires y, sobre todo, obliga a los porteños a compartir con sus nuevos vecinos los derechos sobre las manadas de ganado cimarrón) y disposiciones sobre el comercio de cueros, que quita a la corporación urbana -representante de los intereses ganaderossu control y se establece el libre comercio del bien entre productores locales y comerciantes ultramarinos. A comienzos de los años 1750 una gran victoria local es frenar el intento del Consulado de Lima porque hubiese una diputación en Buenos Aires y se percibiesen derechos en su beneficio.

${ }^{49}$ En 1774 se recibe en Buenos Aires por la vía de Lima la orden de crear una aduana que tasaría con 9\% de almojarifazgo y $4 \%$ de alcabala los bienes que saliesen de la ciudad. El cabildo porteño frena el intento interponiendo una súplica. V. F. Jumar, Le commerce atlantique, p. 326.

${ }^{50}$ Fernando Jumar; Javier Kraselsky, "Las esferas del poder. Hacendados y comerciantes ante los cambios de la segunda mitad del siglo XVIII", en Anuario del Instituto de Historia Argentina, Universidad Nacional de La Plata, 7, 2007, pp. 3158.

${ }^{51}$ Rubén Darío Serrato Higuera, "Las armas del dinero: mecanismos de financiación y administración en la segunda expedición de Pedro de Cevallos al Río de la Plata, 1777”, Tesis de Maestría, Universidad Nacional de Tres de Febrero, 2017. El impacto económico de la militarización en la sociedad es fácil intuir cualquier trabajo que aborda el tema militar. V. p. e. Lía Quarleri, Rebelión y guerra en las fronteras del Plata: guaraníes, jesuitas e imperios coloniales, Buenos Aires, Fondo de Cultura Económica de Argentina S.A., 2009. Pablo Birolo, Militarización y política en el Río de la Plata colonial: Cevallos y las campañas militares contra por portugueses, 1756-1778, Buenos Aires, Prometeo Libros, 2014.

${ }^{52}$ María Emilia Sandrín, Bizcocheras, lancheros y demás... Los estímulos económicos de la guerra para los sectores medios y bajos del complejo portuario rioplatense, 1735-1737, Saarbrücken, Editorial Académica Española, 2011; "La demanda de bienes y servicios para la Corona y la navegación ultramarina en el complejo portuario rioplatense y la dinamización de la economía regional, 1680-1810", Tesis de Doctorado inédita, Universidad Nacional de La Plata, 2016, http://www.memoria.fahce.unlp.edu.ar/tesis/te.1217/te.1217.pdf (consulta 03/02/2019). Fernando Jumar; María Emilia Sandrín, "El gasto público como dinamizador de la economía local. Río de la Plata, en la primera mitad del siglo XVIII", en Ernest Sánchez Santiró (Coord.), El gasto público en los Imperios Ibéricos, siglo XVIII, México, Instituto Mora, 2015, pp. 205-272.

${ }^{53} \mathrm{Si}$ bien se redujo - pero en ningún modo quedó clausurada- la navegación mercantil durante la guerra, a efectos de los factores que dinamizaban la economía regional hay que señalar que llegaron navíos del servicio real y corsarias armadas por el Consulado de Cádiz. V. Enrique Otero Lana, "La escuadra corsaria del Consulado de Cádiz (1779-1783) y su actividad en América”, en Derroteros de la Mar del Sur, 13, 2005, pp. 113-121.

${ }^{54}$ En 1781 y 1782 se temieron invasiones británicas y ello genero todo tipo de preparativos que repercutieron en la economía regional. Por ejemplo, en la alarma de 1781 se ordenó el acopio en Montevideo de víveres para 6.000 soldados. En 1788,
} 
como se ve en detalle en los trabajos de María Emilia Sandrín. Salvo en las fronteras con el mundo indígena independiente (y de modo escaso), los espacios interiores se mantienen calmos tras las rebeliones altoperuanas de 1780-1781 hasta 1809, cuando otra vez haya disturbios en el Alto Perú, pero es otro el actor que los promueve. En 1796 empieza el ciclo final de guerras al que se suman las de las independencias hispanoamericanas en el siglo XIX. La circulación ultramarina sólo recobra una tranquilidad que todos creen durable en los años 1820, pero el escenario ha cambiado por completo.

Si tal puede ser el contexto general, para ponderar los datos hay que considerar que los cinco años retenidos, 1779-1783, presentan desafíos particulares, ya que podrían ser considerados 'anormales' desde la perspectiva circulacionista ${ }^{55}$. Desde este punto de vista, la anormalidad de los años 1779-1783 provendría de dos vías. La primera, la guerra de la independencia de las trece colonias británicas de América del Norte o guerra anglo-española de 1779-1783. La segunda, las rebeliones altoperuanas. Ambas y en tenaza deberían observarse en el comercio del conjunto de mercados americanos considerados a través de una contracción de los flujos y una liberación de fuerzas posterior a su finalización. Lo esperable es que la guerra en el Atlántico entorpezca y hasta anule llegadas y salidas de navíos del comercio ultramarino y que las rebeliones altoperuanas alteren seriamente la demanda del conjunto de mercados interiores y sobre todo en los del Norte que serían los centrales del conjunto virreinal. Todo se cumple, aunque no en los niveles intuidos por la historiografía. Además, esa es la normalidad de la región.

Si se repasa la historia regional rioplatense resulta que al menos desde el último cuarto del siglo XVII lo 'anormal' son períodos sin perturbaciones debido a la guerra o su amenaza. Desde la invasión europea, Río de la Plata se constituye como zona de frontera, tanto con los indígenas independientes como con las potencias rivales de la Monarquía española. Se observa con claridad que desde la guerra de la Liga de Augsburgo (1688-1697) Río de la Plata funge claramente como articulador de circuitos atlánticos e interiores americanos y que los competidores de la Monarquía española piensan que su apropiación redundará en enormes beneficios ${ }^{56}$. Ya no está en el grado de marginalidad que antes la protegía de modo relativo ${ }^{57}$ de las perturbaciones de las guerras de la Monarquía. Desde la instalación de los portugueses de modo durable en la banda norte del río en 1683, la región pasa al rango de frontera caliente para la corona española

\footnotetext{
un nuevo temor de invasión británica, permite saber que acumular raciones para 2.000 hombres durante tres meses requería: 2.433 fanegas de trigo, 2.866 fanegas de harina, 524 fanegas de habas, 1.550 fanegas de carne salada, 230 fanegas de tocino, 30 quintales de yerba, 1.500 gallinas para los enfermos, 100 barriles de vino y 72 de aguardiente. V. Ezequiel Abasolo, Amor al Real Servicio. Don Joaquín del Pino y la organización del Uruguay hispánico, Madrid/Barcelona, Fundación Rafael del Pino/Marcial Pons Ediciones Jurídicas y Sociales S.A., 2006, pp. 128-134.

${ }^{55}$ La idea de 'normalidad' que se maneja en los estudios sobre comercio parece emparentada con lo que en otras disciplinas se llama 'condiciones ideales' en el análisis teórico, que luego son barridas por las condiciones reales en la experiencia sensible. La 'normalidad' en el comercio serían períodos sin elementos que perturben los circuitos afectando el juego de la oferta y la demanda por fuera de las regulaciones institucionales del sistema de poder que aspira a controlarlos. El principal elemento perturbador es, como se sabe, la guerra.

${ }^{56}$ P. e. en Francia había planes avanzados de conquista de Río de la Plata durante esa guerra, pensando articular la posesión de Buenos Aires con penetración del circuito portugués en dirección de Colonia del Sacramento. V. F. Jumar, "El precio de la fidelidad".

${ }^{57}$ Relativamente. Por ejemplo, Martín Wasserman recoge los ecos locales de las guerras de la monarquía de mediados del siglo XVII (principalmente las secesiones portuguesa y de los Países Bajos) en su investigación en torno a formación del mercado de capitales porteño ya citadas.
} 
y a las perturbaciones generales ${ }^{58}$ se suman las locales ${ }^{59}$. Las relaciones con los pueblos indígenas independientes nunca dejan de ser tensas ${ }^{60}$ al tiempo que aumentan los canales de interacción pacífica ${ }^{61}$. Pero sobre todo, si se concentra la observación en lo que resultó ser el tramo final del Antiguo Régimen en la región, 1777-1810/20, la única normalidad es la guerra o su posibilidad. En última instancia Río de la Plata es una frontera múltiple y uno de los focos de atención de la Corona. Ni más ni menos importante que otros, pero es uno de esos en que las vecindades se pueden tornar conflictivas ${ }^{62}$.

De modo que se puede proponer sin exageraciones que la región Río de la Plata y sus circuitos se conforman y viven al ritmo de la violencia o su amenaza inminente. La guerra atlántica y/o local o su amenaza y el temor al indígena son algo permanente e integrado al horizonte de posibilidades. Significan ante todo cambios de estrategias, a veces de interlocutores externos, pero las investigaciones muestran que el comercio parece siempre encontrar su camino. Tal vez esta realidad hiciera que los comerciantes que animaban estos circuitos tuviesen algo particular en su relación con el riesgo y no llenen del todo la caracterización habitual de actores amodorrados por la rutina y seguridades del exclusivismo nacional, y dispuestos a defenderlas a toda costa.

En la coyuntura analizada por la investigación realizada, 1779-1783, el impacto de la guerra de independencia de las trece colonias inglesas de América del Norte debería notarse desde junio de $1779^{63}$ y hasta comienzos de 1782 cuando a pesar de que la guerra sigue, el comercio atlántico se reanima ${ }^{64}$. En tanto que el

\footnotetext{
${ }^{58}$ De las guerras de la monarquía algunas tuvieron Río de la Plata como unos de sus escenarios. Tal vez marginal para el curso general de la guerra, pero de hondo impacto local: guerra de sucesión (1701-1715); de la cuádruple alianza (17181720); anglo-española de 1727; de la oreja de Jenkins (1739-1748) que empalma con la de sucesión austríaca (1740-1748); de los siete años (1756-1763), guerra anglo-española de 1796-1802, guerra de "las naranjas" de 1801, guerras napoleónicas (1804-1809) que incluyen la invasión inglesa a Río de la Plata de 1806-1807.

${ }^{59}$ Los esporádicos malones y sus respuestas, las malocas; expulsión de los portugueses de la banda norte en enero de 1680; sitio y conquista de Colonia entre octubre de 1704 y marzo de 1705; fallido intento de expulsión de los portugueses entre 1735 y 1737; las rebeliones paraguayas que entre 1724 y 1731 que obligan al gobernador de Buenos Aires a despachar fuerzas; guerra guaranítica (1754-1756); guerra anglo-española de 1779-1783; las rebeliones altoperuanas que movilizan tropas asentadas en Buenos Aires (1780-1781); ecos de guerras generales asociadas a la Revolución Francesa y el imperio napoleónico (expedición contra Rio Grande do Sul en 1801, invasión inglesa entre 1806 y 1807); rebeliones altoperuanas de 1809 que movilizan fuerzas porteñas; guerra de la independencia desde 1810; guerras entre espacios americanos desde 1811.

60 "De acuerdo a la evidencia disponible, el problema del malón que enfrentaban las autoridades bonaerenses y mendocinas era creciente. Durante la primera mitad de la centuria [siglo XVIII] se registraron 9 ataques, mientras que tan solo en la década de 1750-1760 se registró una cifra similar. No obstante, fue durante el período 1760-1780 cuando los malones alcanzaron su máximo apogeo, (...)". Leonardo León Solís, "La guerra contra el malón en Chile, Cuyo y Buenos Aires, 1750-1800", en Cuadernos de Historia, Universidad de Chile, 17, 1997, pp. 7-67, p. 10.

${ }^{61}$ Se intensifican después del establecimiento de la llamada "línea de Vértiz" en 1780 (una línea de fortines que dibuja la frontera en la Pampa hasta tiempos de la revolución de independencia). V. p. e. Antonio Galarza, "Relaciones interétnicas y comercio en la frontera sur rioplatense. Partidas indígenas y transacciones comerciales en la Guardia de Chascomús (17801809)", en Fronteras de la Historia, 17, 2, 2012, pp. 102-128. Sebastián L. Alioto, "Dos políticas fronterizas y sus consecuencias: diplomacia, comercio y uso de la violencia del fuerte Carmen de Río Negro (1779-1785", en Prohistoria, $17,21,2014$, pp. 55-84

${ }^{62}$ Sobre la propuesta en torno al estudio de las ‘vecindades', v. José Javier Ruiz Ibáñez, Las vecindades de las Monarquías Ibéricas, Madrid, Fondo de Cultura Económica, 2013.

${ }^{63}$ Desde junio de 1779 se ve al virrey Vértiz aplicando órdenes secretas para que evite la salida de navíos cargados, aunque aún no había estallado la guerra. En septiembre se publica en Buenos Aires el inicio formal de la guerra y se ordena formalmente el cierre de los puertos rioplatenses. Pero no se cierran realmente, sólo se toman muchas precauciones. La principal es que la navegación se dé bajo la forma de convoy protegido por corsarias fletadas por el Consulado de Cádiz y/o navíos de guerra. Pero también navegan embarcaciones sueltas. En 1782 se nota que la situación se ha relajado y empiezan abandonarse los cuidados. La neutralidad portuguesa en la guerra permitió que, como había pasado siempre que no estaba en guerra con la corona española, se utilizase su circuito mercantil como conducto del comercio legal español. Además, se concedieron licencias especiales de comercio a portugueses y se suma el tráfico de embarcaciones medianas de contrabando. En 1781 y 1782 las naves portuguesas son más que las españolas en el río. J. C. Garavaglia, "El comercio virreinal”, pp. 6 21; Corcino Medeiros dos Santos, O Rio de Janeiro e a Conjuntura Atlântica, Rio de Janeiro, Expressão e Cultura, 1993. ${ }^{64}$ Josep Fàbregas Roig, "El libre comercio de Cataluña con América durante la guerra de las trece colonias, 1779-1783", en Carlos Martínez Shaw; María Alfonso Mola (Coords.), España en el comercio marítimo internacional (siglos XVII-XIX).
} 
esperable impacto negativo de los disturbios altoperuanos debería notarse desde comienzos de 1781 y hasta algún tiempo después de noviembre del mismo año.

Ambos impactos están presentes en los circuitos observados. En otro orden de ideas, se podría postular que la contracción -que no fue cierre- del comercio ultramarino en el período si bien fue ciertamente mala para los negocios, fue buena para la instalación de todas las novedades administrativas. Ello podría ser por el menor volumen de operaciones con que debieron lidiar los servidores reales encargados de tornar reales los diseños institucionales propios del virreinato y sus sistemas de gobierno y de rentas, que se siguen complejizando (1783 inicio de creación efectiva de las Intendencias ${ }^{65}$, 1785 inicio de la Audiencia de Buenos Aires).

Finalmente, si desde las cifras conocidas para algunas variables mercantiles para períodos posteriores muestran que los años 1779-1783 no son buenos, la apreciación cambia si se mira desde el período 1680-1778. Se estaría ante un notable crecimiento $^{66}$, como señala M. Camarda ${ }^{67}$, aunque menos importante de lo que sugieren las cifras si se considera que las anteriores a 1778 acusan la falta de las del circuito legal portugués, sólo buenas para los años 1720-1730. Si se proyectan las cifras de esos años el crecimiento que acusan las investigaciones desde los años 1760 mirando sólo el circuito español sin dudas continúa la tendencia abierta a comienzos del siglo XVIII, sobre todo en lo relacionado con la exportación de cueros ${ }^{68}$.

De modo que lo que posiblemente pase cuando se sostiene que la circulación sufre ante la doble perturbación interna y atlántica es que la historiografía no encuentra en el período el crecimiento que esperaba ver tras el libre comercio y que las cifras recién se acomodan a esa imagen tras la guerra. Del mismo modo, la idea de que el comercio rioplatense y la economía regional inician su crecimiento en los años 1760 se relativiza si se considera que hay paneles enteros de información desconocida para los años 1740-1760.

\section{6.- El sub-registro y el comercio directo}

Las diversas formas que asume la evasión fiscal en temas mercantiles son un viejo tema en la crítica de las series obtenidas a partir de fuentes generadas en las instancias de control del respeto de las normas y de percepción de derechos. El comercio ilícito ocupa un inmedible, pero enorme, lugar por el modo en que se lo incluye en las explicaciones. Siempre existe. La cuestión es su proporción en

\footnotetext{
Quince estudios, Madrid, UNED, 2010, pp. 394-425. Para dar contexto a sus análisis de la presencia catalana en los circuitos el autor analiza los datos generales existentes de la circulación ultramarina por dentro del circuito legar español y de allí emerge lo señalado.

${ }^{65}$ V. F. Jumar, "Hay para todos”, Mapa 3.

${ }^{66} \mathrm{Si}$ nos dejamos guiar por el comercio ultramarino, entre 1779 y 1783 J. C. Garavaglia consigna el paso de 53 navíos mercantes debidamente registrados. En el quinquenio previo, 1774-1778, se registró la salida de 20 navíos mercantes, más 23 fragatas-correo y 56 de guerra. Los volúmenes del comercio de importación sólo se pueden ponderar en función de los navíos mercantes, ya que fragatas-correo y los navíos del servicio real sólo transportan cargas en sus viajes de regreso a Europa. Aunque sería altamente imprudente hacer estimaciones en función del número de navíos o de toneladas en temas de comercio, el dato de que hay más navíos mercantes necesariamente tiene que querer decir que hay más comercio. Sobre el tema de las estimaciones en base a las toneladas, v. Michel Morineau, Jauges et méthodes de jauge anciennes et modernes, París, Librairie Armand Collin, 1966 y "Tonnage et cargaison. Codicille à une étude de la Carrera de Indias", en Revue belge de philologie et d'histoire, 79, 4, 2001, pp. 1159-1211.

${ }^{67}$ M. Camarda, "Algunos datos".

${ }^{68}$ V. F. Jumar, "El comercio ultramarino”, Cuadro 10, p. 252 y Gráfico 7, p. 253.
} 
relación al comercio registrado. Es sabido que los datos de la fiscalidad hablan más de la capacidad de percepción de derechos que de la economía real, y los datos que se manejan ahora no escapan a la regla.

El consenso es que las cifras del comercio ilegal (visto desde la normativa española) en Río de la Plata podrían hacer empalidecer las del comercio legal. Se lo conoce sobre todo por tres vías. La primera son las fuentes cualitativas generadas en diversos niveles de la Monarquía, que se lamentan y/o analizan el fenómeno, proponen soluciones o intentan ponerlas en práctica. La segunda son los decomisos ${ }^{69}$, también accidentes que revelan cargas no declaradas (p.e. naufragios). La tercera vía son milagrosos hallazgos en los archivos de fuentes privadas que contienen informaciones sobre este tipo de tratos. Una cuarta vía, menos frecuentada, es estudiar el comercio directo a partir de sus puntos de origen en los que supuestamente habría dejado más huellas. ${ }^{70}$

Se proponen diversas correcciones a las cifras del tráfico legal, muchas veces malinterpretando las aportadas por Michel Morineau ${ }^{71}$ o elaborando ingeniosos y complejos cálculos. Pero lo cierto es que siempre se vuelve a la consideración primera del problema: es una variable inmedible, que escapa a toda estadística por la cantidad de variables que a su vez entran en su composición, que impiden proyectar hacia el conjunto de tratos los casos puntuales detectados. De allí que, en fin de cuentas, cada investigación termina proponiendo una ponderación sobre el lugar del comercio ilegal en la observación realizada y esa valoración es determinante en la explicación final propuesta sobre el comercio, la economía y la sociedad. Esta investigación también lo hace.

En general, la historiografía se hace eco de las apreciaciones de las autoridades españolas en cuanto a la masividad del contrabando, pero leyéndolas en claves diversas. Bartolomé Mitre ${ }^{72}$ y casi un siglo después Manfred Kossok ${ }^{73}$ formularon, ciertamente con muy distinto lenguaje, la misma idea que aún opera en la historiografía. El contrabando habría tenido una suerte de función revolucionaria, ya que el comercio ilegal es reflejo de una innata inclinación al librecambio entre los americanos (aún antes de que se formulara la doctrina) y es base de una justa desobediencia basada en el derecho natural (Mitre) o que revela resistencia anticolonial (Kossok) que figura entre los elementos que intervienen en la parte ideológica del proceso de formación de una burguesía y de las independencias. La revolución económica precede a la política.

\footnotetext{
${ }^{69}$ V. Fernando Jumar; Isabel Paredes, "El comercio intrarregional en el complejo portuario rioplatense: el contrabando visto a través de los comisos, 1693-1777”, en América Latina en la Historia Económica, 29, 2008, pp. 33-99.

${ }^{70}$ Esta presunción metodológica supone que los comerciantes franceses, portugueses, ingleses y holandeses no evadían. En el caso del comercio directo francés de comienzos del siglo XVIII con Río de la Plata y las costas del Pacífico sur los comerciantes de Saint-Malo ponían tanto ingenio en defraudar a Luis XIV como los rioplatenses a su nieto. P. e. ante decisiones de Versalles relacionadas con reacuñar toda la plata llegada de los dominios españoles, los malvinos antes de llegar a puerto se encontraban con navíos que regresaban de la pesca del bacalao en Terranova, ocultaban las piastres en los barriles de pescado y se remitían a los Países Bajos donde se obtenían premios más elevados.

${ }^{71}$ Contrariamente a la idea establecida, Michel Morineau no aporta cifras sobre el fraude por dentro de los circuitos español ni portugués, tampoco del comercio directo. Sobre el tema, v. F. Jumar, "El comercio ultramarino", pp. 181-183.

${ }^{72}$ Bartolomé Mitre, Historia de Belgrano y de la Independencia Argentina, $4^{\mathrm{a}}$ ed. definitiva, 3 Tomos, Buenos Aires, Editorial Félix Lajouane, 1887.

${ }^{73}$ Manfred Kossok, El Virreynato del Río de la Plata. Su estructura económica y social, Buenos Aires, Editorial Futuro, 1959.
} 
Esta línea de pensamiento prevaleció hasta los análisis de Zacarías Moutoukias para el siglo XVII porteño. Considera que es gracias al comercio ilícito que en el momento que estudia la Corona pudo asegurar su soberanía en la región rioplatense, ya que era el atractivo para que hubiese quienes comprasen por elevadas sumas cargos a desempeñar en Buenos Aires. ${ }^{74}$ Así, el contrabando no es un elemento estructural que corroe el orden, sino parte integrante del mismo y colabora con su consolidación aunque desvíe recursos de las arcas de la Corona. En el período analizado ahora, María Evangelina Vaccani encuentra asombrosas continuidades aunque resignificadas para explicar lo que lleva al enjuiciamiento del primer Administrador de la Aduana de Buenos Aires (1779-1788). ${ }^{75}$ Es el enfrentamiento entre la monarquía compuesta y la administrativa, en un contexto de poderes policéntricos.

En otro registro de ideas, que busca evaluar el impacto del contrabando en la economía, Carlos Sempat Assadourian concluye que en relación al espacio peruano,

El contrabando estuvo lejos de significar el surgimiento de una fuerte y continuada demanda de materias primas (aunque podrían haber sido el caso de Guayaquil, el cobre de La Serena y los cueros de Buenos Aires), sino más bien la evasión de metálico. De ahí que esta forma ilegal de relación con economías desarrolladas situadas fuera del orden colonial sólo origina en el espacio peruano los siguientes efectos: 1) no dinamiza ni incita al crecimiento de los sectores externos regionales; 2) al ocupar el lugar que deja la crisis del sistema mercantil monopolista español, mantiene la tendencia al consumo suntuario del grupo social dominante; 3) a través de la evasión de oro y plata habría agudizado -o mantenido- la tendencia descendente de los precios, si es que dicha tendencia se explica en parte por factores monetarios; 4) constituye un elemento disruptivo con respecto a las formas de integración regional del espacio peruano al dislocar la estructura de los circuitos comerciales externos e internos. Fundamenta el ascenso de Buenos Aires y la hegemonía del puerto atlántico sobre el interior del espacio peruano, en competencia con Lima. ${ }^{76}$

Para los años 1779-1783, Juan Carlos Garavaglia tiene datos de contrabando portugués y, lógicamente del aliado francés, pero no carga las tintas con el asunto ni avanza intuiciones sobre su importancia en la coyuntura. ${ }^{77}$ Toda la bibliografía que por algún motivo tiene que dar así sea un contexto mínimo de Río de la Plata, en los años observados o en general, que incluya la economía, menciona el contrabando y le atribuye proporciones asombrosas.

Al fraude en la circulación ultramarina se suma el practicado en los circuitos interiores. Eduardo Saguier presenta mecanismos de manipulación de las guías de aduana ${ }^{78}$ por parte de los comerciantes del interior:

\footnotetext{
${ }^{74}$ Z. Moutoukias, Contrabando y control colonial, pp. 204-205.

${ }^{75}$ María Evangelina Vaccani, "La Real Aduana de Buenos Aires y la quiebra de su primer administrador: Francisco Ximénez de Mesa. Dominación y control en una sociedad de Antiguo Régimen”, en El Taller de la Historia, 12, 2019, pp. 58-86.

${ }^{76}$ Carlos Sempat Assadourian, "Integración y desintegración regional en el espacio colonial. Un enfoque histórico", en EURE, Revista Latinoamericana de Estudios Urbanos Regionales, 2, 4, 1972, pp. 11-24, p. 19.

77 J. C. Garavaglia, "El comercio virreinal”, pp. 14-18.

${ }^{78}$ No son lo mismo que las notas de aduana, sino un documento derivado de ellas que contiene menos información.
} 
... los comerciantes del interior solían defraudar al fisco manipulando las guías de aduana. El mecanismo más común era sacar guías fraudulentas declarando cargas semejantes pero de inferior valor, que si bien podían tener igual gravamen en el lugar de expedición no lo tenían en el lugar de destino. Este fue el caso, por ejemplo, del aguardiente de San Juan que so capa de cargas de vino era expedido a Córdoba y las provincias del Alto Perú. Según el abogado Juan José Castelli menos del quince por ciento de las cargas de aguardiente que entraban en Córdoba traían guía. También solían los comerciantes sacar sus guías de aduana entre los Tesoreros de la Real Hacienda de cada cabecera provincial para introducir sus mercaderías en destinos geográficos preestablecidos, y en su lugar comercializar la mercancía en puntos intermedios. Con lo que los comerciantes no pagaban los gravámenes ni en el destino fingidamente prefijado ni en el efectivamente arribado. Finalmente, los comerciantes retornaban la guía al Tesorero, quedando este último cubierto y el fisco defraudado. ${ }^{79}$

En 1788 estalla un escándalo en la administración de la Aduana de Buenos Aires por irregularidades que databan desde 1779, que analiza María Evangelina Vaccani como ya se mencionó. Las acusaciones contra el Administrador y un selecto grupo de asociados hacen hincapié en el uso de los fondos recaudados para financiar actividades privadas (salazón de carnes, negocios navieros, envío de bienes de producción local a Lima, La Habana y Cádiz), pero también se menciona circulación de bienes sin registrar -principalmente llegados por el circuito portugués- hacia los mercados interiores.

Se puede seguir sumando aportes que registran la presencia del fraude fiscal en todos los niveles. Son tantos los testimonios que se refuerzan las hipótesis sobre la masividad del fenómeno. En tal contexto explicativo, las cifras del comercio legal servirían para bien poco. A lo sumo para dibujar circuitos y conocer la composición de la oferta.

Pero la historiografía también se puede hacer eco de otra línea argumental, también presente entre los servidores de la Corona en papeles distintos a los que se lamentan del contrabando: las perturbaciones del tráfico por la guerra generan carestía. ${ }^{80}$ Así, el contrabando pierde importancia porque aún si existe, no llega a compensar el volumen del tráfico legal.

Hernán Asdrúbal Silva, presenta las distintas modalidades que asume el comercio ultramarino durante la guerra anglo-española de 1779-1783 y avanza algunas cifras que dan idea del orden de tamaño. Pero llegada la hora del balance, a partir de los testimonios citados, considera que lo percibido es poco,

\footnotetext{
${ }^{79}$ Eduardo Saguier, Genealogía de la tragedia argentina (1600-1900). Auge y Colapso de un fragmento de estado o la violenta transición de un orden imperial-absolutista a un orden nacional-republicano. Tomo II, sección G, Capítulo 21, https://www.er-saguier.org/obras/gta/Tomo-II/Seccion-G/Cap-21/0-BUR-12.pdf (consulta 05/02/2019).

${ }^{80} \mathrm{El}$ argumento usualmente es esgrimido para legitimar la autorización de venta de bienes aportados por navíos que declararon arribada forzosa. Un mecanismo bien estudiado por Z. Moutoukias y que reaparece en el río tras la expulsión de los portugueses de Colonia del Sacramento. Z. Moutoukias, Contrabando y control colonial.
} 
Pese a la búsqueda de medidas colaterales para paliar la crisis provocada por la guerra, sus efectos se hicieron sentir en el medio rioplatense. Géneros de consumo masivo comenzaron a escasear e incluso desaparecieron del mercado, provocando un aumento considerable de los precios." ${ }^{81}$

En síntesis, hay buenos argumentos de ambos lados. Para terciar en el asunto, se puede traer a colación un problema sobre el que no se abunda demasiado a la hora de enfrentar el tema del volumen e impacto del contrabando: la capacidad de consumo de los mercados involucrados en la circulación anudada en el complejo portuario rioplatense, es decir, qué lugar queda para el comercio ilegal tras el paso del comercio legal.

En buena medida, el interés por el tema del consumo ha sido abordado para establecer consumidores ideales de los distintos tipos de bienes (en asociación a explicaciones de la base económica de la colonialidad). Ana Clara Gastaldi y Mariel Esjaita sintetizan en función de sus observaciones las problemáticas asociadas al estudio del consumo ${ }^{82}$.

En función de este texto, es necesario recordar que la idea establecida es que los efectos de Castilla en general y en particular los textiles estaban destinados a las capas sociales altas ${ }^{83}$ y cubrían mayormente consumo suntuario, mientras que los sectores subalternos -cuando recurren al mercado- consumen mayormente efectos de la tierra. En ese consumo diferencial se ve uno de los elementos de la dominación colonial dentro del esquema que entiende que los territorios americanos de la Monarquía Hispánica eran un conjunto de mercados cautivos y fuentes parasitarias de renta de España.

Algunos datos pueden ayudar a pensar en la pertinencia de plantear todo el problema nuevamente. Se trata de cifras de textiles que salen de Buenos Aires. Como siempre, tienen sus limitaciones. No dan datos del consumo en Buenos Aires y tampoco se los tiene para la distribución desde Montevideo hacia su hinterland ni la mayor parte del consumo en la ciudad. Además, quedan fuera de la observación la tejeduría doméstica que no pasa por el mercado ni la circulación de textiles de la tierra que sí lo hacen pero que no pasaban por Buenos Aires ${ }^{84}$. Tampoco se ven los textiles extra-americanos que podían llegar a los mercados involucrados de modo legal por otros caminos. ${ }^{85}$ Es decir, son mínimos, lo que en este caso resulta beneficioso por el viejo principio de trabajar con los datos cuantitativos más negativos para la hipótesis que se busca delinear.

\footnotetext{
${ }^{81}$ H. A. Silva, El comercio entre España y el Río de la Plata, p. 22.

${ }^{82}$ Ana Clara Gastaldi, Mariel Esjaita, "Aproximaciones a la estructura socioeconómica desde un enfoque sociocultural: el consumo como vía a la identidad en el Río de la Plata virreinal", en El Taller de la Historia, 12, 2019, pp. 243-266.

${ }^{83}$ Sobre esta categoría v. Bernd Schröter; Christian Büschges (Eds.), Beneméritos, aristócratas y empresarios. Identidades y estructuras sociales de las capas altas urbanas en América hispánica, Madrid, Verbuert-Iberoamericana, 1999.

${ }^{84}$ P. e. la tejeduría del algodón en Paraguay y en los pueblos de las misiones que bien podían redistribuirse desde Santa Fe o los tocuyos cochabambinos que desde el espacio salto-jujeño se dispersaban por todos los circuitos, incluido el rioplatense. También, los tejidos de lana ovina o de camélidos americanos.

${ }^{85} \mathrm{P}$. e. en función de las propuestas que hace Mariano Bonialian cabría esperar ver la circulación de textiles asiáticos en proveniencia de los circuitos del Pacífico por Mendoza-San Juan y por Lima-Alto Perú-Salta-Jujuy. Mariano Bonialian, China en América: bienes, mercados, comercio y cultura del consumo desde México hasta Buenos Aires, Buenos Aires, Biblos/Instituto Mora, 2014. También hay que considerar los caminos de contrabando entre los dominios portugueses y el litoral rioplatense y Paraguay.
} 
Con todas esas limitaciones (y seguramente otras que se me escapan), se ve que entre 1779 y 1783 , en unos mercados en teoría perturbados por una doble coyuntura conflictiva y también en teoría inundados por bienes de contrabando, se registra la salida legal de Buenos Aires de 4.578.347,51 varas de telas al corte $^{86}, 153.222$ prendas de vestir confeccionadas y 946 cortes de tela para elaborar distintos tipos de prendas a tal fin ( $\sin$ datos sobre las varas de cada corte $)^{87}$; 97.544 pares de calcetas, medias o polainas ${ }^{88} ; 621$ pares de otras prendas $^{89} ; 278.388$ accesorios del vestir textiles ${ }^{90}$ y 5.069 declaraciones de conjuntos de "ropa de uso" asociadas a personas que se mueven"1. Los artículos de mercería ${ }^{92}$ y accesorios del vestir no textiles también son numerosos ${ }^{93}$.

Uno de los problemas de base con este tipo de datos es determinar si es mucho o es poco. Por mi parte pienso que lo consignado es mucho, me atrevería a proponer que muchísimo, en realidad, si se recuerdan además los textiles que no se ven circular. Se puede sostener la apreciación en un muy grosero cálculo de consumo potencial que tome simplemente datos sobre población, sobre consumo medio detectado del bien y cantidad del mismo necesaria para cada consumo. Entre todos esos textiles hay unas telas de lino que entre sus usos predominantes estaba la confección de camisas. En total suman 2.894.465,97 varas $^{94}$.

Se consideran los espacios que son provistos desde el complejo portuario rioplatense de modo ampliamente dominante: Centro; dentro de Oeste, Mendoza,

\footnotetext{
${ }^{86} 238.473,28$ varas de algodón; 356,5 de cáñamo; 904.246,72 de lana; 3.251.748,09 de lino; 183.522,92 de seda. Para tener una idea de qué pueden significar estas varas, la confección de una camisa requería 4 varas de tela, también con 4 varas se hacían unas chupas y un calzón, las polleras podían insumir entre 5 y 11 varas (dependiendo del modelo), 6 varas para una capa, 14 varas para un vestido de mujer; 6 varas para un surtú. RegAduAR, base 1779-1783.

${ }^{87} \mathrm{Sin}$ diferenciar entre piezas confeccionadas y cortes al efecto, tampoco entre las distintas fibras y calidades: 2 amitos; 2.068 armadores; 33 basquiñas; 11 batas; 13.479 calzoncillos; 25.756 calzones; 22.146 camisas; 198 capas; 2 capingos; 57 capotes; 14 casacas; 4.012 ceñidores; 8.015 chalecos; 1.324 chamarras; 120 chaquetas; 6.460 chupas; 8 corpiños; 32 cuellos; 625 delantales; 42 delanteras; 3 enaguas; 3 faldellines; 1 fraqué para dama; 65 hábitos religiosos (seculares y regulares para diversas jerarquías, para vestir imágenes piadosas); 381 justillos; 1 mandil; 788 mantas; 1 manto; 3 mantones; 5 mortajas; 4 petos; 267 polleras; 66.624 ponchos; 48 redondeles; 86 respetosas; 57 sagalejos; 90 sayas; 803 surtues; 2 tapafundas; 11 uniformes (todos para militares de graduación menos una librea para un lacayo); 196 "vestidos" (que no remiten a una prenda femenina sino a una vestimenta completa de hombre o de mujer). Dos curiosidades: también se despacha a Chile un hábito de la Orden de Carlos III y 53 quillapis a Lima y Europa. RegAduAR, base 1779-1783.

${ }^{88}$ En distintas fibras: 8.987 pares de calcetas; 82.538 pares de medias; 6.109 pares de polainas. RegAduAR, base 17791783.

${ }^{89}$ En distintas fibras: 288 pares de puños para camisas; 53 pares de solapas; 36 pares de volantes; 129 pares de vuelos; 109 pares de vueltas. RegAduAR, base 1779-1783.

${ }^{90}$ En distintas fibras: 2.740 barbijos; 624 birretes; 72 boinas; 187 bonetes; 12 bufandas; 29 cabriolets; 2.413 pares de charreteras; 2 cofias; 47 corbatines; 121 cotillas; 233 fajas; 46.638 gorros; 1.070 pares de guantes de seda o hilo; 1.731 pares de ligas; 56 manguitos; 319 mantillas; 21 monteras; 12 pañoletas; 140.853 pañuelos; 53 rebozos; 21.304 redecillas; 59.702 sombreros; 149 tocas. RegAduAR, base 1779-1783.

${ }^{91}$ Cada registro de este tipo no remite necesariamente al equipaje de una sola persona, ya que cuando se mueven grupos (p.e. una familia, un grupo de troperos, un individuo y personal de servicio), se hace una sola declaración por el conjunto. Por algunos casos en que hay algún detalle en la descripción de la composición del equipaje se ve que se trata de ropa usada y nueva, "avíos de cocina" (elementos para cocer alimentos durante los viajes), catres, colchones y ropa de cama ("avíos de dormir"). En ocasiones se menciona como parte del equipaje, pero sin dar cantidades ni detalles, telas al corte y/o prendas compradas para familiares o para satisfacer encargos en el lugar de destino. También estas notas contienen alimentos.

${ }^{92}$ Por ejemplo, salen de Buenos Aires 3.603.812 botones de diverso tamaños, materiales, calidades y hasta usos específicos para cierto tipo de prendas. Hay muchos hilos, pero no se pudo reducir su diversa metrología a un común denominador. Sí se pudo estimar el vareaje de las cintas que presentaban el mismo problema, y en muchas variedades se habrían despachado 1.810.581,15 varas. RegAduAR, base 1779-1783.

${ }^{93}$ P. e. 4.215 pares de calzados (zapatos de diverso tipo, material y calidad, así como botas y botines); 5.724 hebillas para zapatos. RegAduAR, base 1779-1783.

${ }^{94}$ Se trata de bretaña $(1.292 .982,75$ varas), cambrai $(2400,5)$; cambrayeta $(346,5)$, caserillo $(186.618,5)$, clarín $(14.632,25)$, crea $(31.137,5)$, crehuela $(10.674,4)$, estopilla, estopilla olán y clarín $(80.928,66)$, holandilla $(366)$, lienzo $(69.125,8)$, olán, olán batista y clarín $(10.112,75)$, platilla $(96.036,88)$, platilla real $(123.854,5)$, presilla $(671)$, puntibí $(740.957,53)$, royal (4.190), ruan (227.421,45). En total, 2.894.465,97 varas. RegAduAR, base 1779-1783. La 'camisa' en el período no es la prenda actual, sino una prenda interior/exterior que mezcla las funciones de la camisa actual y del camisón de dormir. También, a los más pobres les sirve de mortaja.
} 
San Juan y San Luis y Salta y Jujuy dentro de Norte. ${ }^{95}$ En relación a los linos registrados para los distintos conjuntos espaciales, parte de los realizados para Salta-Jujuy y Mendoza-San Juan (y en mucha menor medida San Luis) son reenviados hacia el Alto Perú y Chile y las costas del Pacífico sur respectivamente. También, se sabe que Córdoba articulaba con el Alto Perú. Por tanto, se torna necesario aplicar alguna hipótesis que contemple el hecho para no sobrerepresentar las varas de tela consumidas en sus regiones. En el caso de Centro, se deja para el consumo regional $75 \%$ de los textiles de linos camiseros (419.902,3 varas). En los envíos a Salta y Jujuy por un lado y a Mendoza, San Juan y San Luis por otro lado, se estima que $1 / 4$ se consumen a escala regional (115.762,87 varas y $100.445,96$ varas respectivamente). Como las camisas no eran el único uso de esos textiles, se toma que $75 \%$ se destinaba a tal fin, con lo que la cifra final retenida para el cálculo es de 477.083,34 varas de linos camiseros.

En relación a las cifras de población, afortunadamente se cuenta con datos que han sido tomados por buenos y aceptados los resultados de los cálculos realizados con ellos. Están en un trabajo de Jorge Gelman y María Inés Moraes. ${ }^{96}$ Así, se tomará como base la cantidad de 149.396 personas. ${ }^{97}$ En cuanto al consumo por individuo, numerosas fuentes indican que en promedio se necesitan 4 varas de tela para una camisa y se elige como orientación datos provenientes del consumo anual de bretaña (el más difundido de esos linos camiseros) por parte de un cura doctrinero radicado en Sonora (Nueva España). Anualmente requería a su obispo 3 piezas de bretaña (24 varas). Con dos piezas se mandaba confeccionar 4 camisas (16 varas) y con la restante paños menores. ${ }^{98}$ Mientras llegan los datos de las investigaciones en curso de Ana Clara Gastaldi y de Mariel Esjaita que entre otras cosas permitirán saber la cantidad de camisas presentes en los inventarios post mortem por lo alto y por lo bajo de la sociedad rioplatense ${ }^{99}$, se retiene la idea de que cuatro camisas de bretaña por año pueden revelar el consumo de un miembro medianamente prestigioso de la sociedad (en fin de cuentas, no es más que un cura doctrinero).

Las cuentas hechas, se tiene una estimación de consumo de 2,45 camisas de lino por habitante entre 1779 y 1783 en Centro, Cuyo y Salta-Jujuy o si se prefiere 0,49 por año. No es nada frente a las cuatro camisas anuales del cura novohispano, aunque más que la imagen bibliográfica que sostiene que sólo las

\footnotetext{
${ }^{95}$ V. F. Jumar, "Hay para todos", tablas 2 a y b. Se deja de lado Río de la Plata por las deficiencias ya apuntadas de la fuente para observar el consumo de las ciudades de Buenos Aires y de Montevideo así como las redistribuciones hechas desde Montevideo de bienes no llegados desde Buenos Aires. Sería un abuso intentar el cálculo para Chile, por ejemplo, contando sólo con los linos llegados desde el Atlántico por Río de la Plata-Mendoza/San Juan. De modo inverso, por más que tal vez algún lino entre en Córdoba por el camino inverso, estoy convencido de que las cantidades no afectarían el cálculo realizado con los llegados desde Río de la Plata.

96 J. Gelman; Ma . I. Moraes, "Las reformas borbónicas", Cuadro 3: "Estimaciones de población total por subregiones, 1778 y ca. 1810 ", p. 67. Se toman los datos para 1778.

${ }^{97}$ Centro 100.801 personas; Mendoza, San Juan y San Luis 23.411; Salta y Jujuy 25.184.

98 “...una pieza de Bretaña ancha y otra angosta para cuatro camisas que en tiempo regular importan veinticinco pesos. Ítem de hechuras y avíos cinco pesos. Ítem una pieza de Bretaña entreancha para paños menores que vale nueve pesos. Ítem avíos y hechuras, dos pesos." Regulación del Obispo de Sonora fray Francisco Rouset (1798-1814), apud Alfredo Jiménez, El Gran Norte de México. Una frontera imperial en la Nueva España (1540-1820), Madrid, Tébar, 2006, pp. 321-322.

${ }^{99}$ Mariel Esjaita para los difuntos ab intestato de Buenos Aires que claramente no pertenecen a las elites y Ana Clara Gastaldi para los de la elite porteña a partir de sus testamentarias. La percepción emergente por el momento del simple procesamiento de las fuentes con criterios estadísticos en cuanto a los ajuares invita a pensar que los más pobres no solían tener más que la camisa que llevaban puesta y les servía de mortaja mientras que las capas sociales altas tenían entre 2 y 3 camisas, en distinto estado (desde "buena" a "muy remendada" según la valoración de los tasadores para justipreciarlas).
} 
elites consumen bienes ultramarinos. Si se mantiene la idea de que los efectos de Castilla son consumidos por las capas sociales altas y se quiere detectar cuántas personas las componían a través del consumo del cura novohispano, ese sector social podría estar conformado por 59.635,41 personas en los espacios observados, 39,92\% de la población. Por más imprecisa que en la bibliografía aparezca la categoría "elites", parece mucha gente.

Al considerar que sólo se calcula un uso potencial de 10,42\% de todos los textiles al corte puestos en circulación, se recuerdan las prendas confeccionadas o cortes para confeccionarlas y demás textiles, lo mismo que las deficiencias de las cifras en cuanto a representatividad para el consumo intrarregional y el tema del contrabando, se podrían formular dos hipótesis: a) que el contrabando no era masivo; b) que hay bienes puestos en circulación desde Buenos Aires, sean efectos de Castilla o de la tierra, que tienen su mayor mercado en los sectores ajenos a las elites, que hay para todos.

Ante las cifras del comercio legal y el modo en que las proyecto, si el contrabando tuviese la masividad esperada habría que preguntarse sobre la caracterización de las economías americanas en general. ${ }^{100} \mathrm{Si}$ además de los textiles contabilizados, el contrabando fuese masivo y alimentase el consumo de las elites de modo preferencial, serían todavía más extensas que el grosero cálculo apuntado. Finalmente, considerando que se observan tiempos perturbados, cabe preguntarse por lo que revelarán tiempos más calmos. Por ejemplo, si serán otras las orientaciones dominantes y cómo serán los niveles de consumo. Son temas que quedan pendientes en espera de más informaciones, pero por el momento parece que lo más prudente es poner en suspenso las explicaciones clásicas sobre ellos y reducir el tamaño del contrabando en las especulaciones.

En síntesis, no parece desatinado pensar que, al fin y al cabo, y aunque oculten sub-registro y haya contrabando, las cifras del comercio legal español tras $1777^{101}$ son más que suficientes para conocer no sólo las articulaciones espaciales

\footnotetext{
${ }^{100}$ Hay otra posibilidad para explicar las cifras avanzadas. Podría ser que el contrabando exista en los niveles sospechados por la historiografía en el complejo portuario rioplatense, pero que los bienes se legalicen para la circulación interior. Salvo los bienes de circulación prohibida, en la práctica era imposible diferenciar entre bienes de los circuitos legal e ilegal una vez que llegaban a los almacenes. Lo que tal vez podía pasar desapercibido en Buenos Aires podría no serlo en mercados más chicos o en los controles en los caminos. Sin embargo, es un argumento sin indicios que lo sustenten y sólo pensado para sostener la idea de la existencia del contrabando que suele ponderar la historiografía. Sólo se podría verificar mediante la realización de una balanza comercial del circuito legal que arrojase como resultado que se ponen en circulación hacia el interior americano por el circuito legal más bienes que los llegados al complejo portuario rioplatense por el mismo circuito, tarea que por ahora no se puede encarar ya que requiere investigar en diversos archivos españoles además de los rioplatenses. Todos los trabajos sobre el comercio ultramarino rioplatense en el período virreinal en algún momento afirman la imperfección de sus cifras por no constarse en los archivos locales con fuentes que permitan construir series confiables. Lo mismo sucedía para el período 1680-1778 que investigué en su momento. Complementando los fondos locales y españoles se alcanzaron resultados satisfactorios (v. Fernando Jumar, "El comercio atlántico del Río de la Plata, 1680-1777. El circuito legal español. Las fuentes utilizadas y su tratamiento", en: América Latina en la Historia Económica. Boletín de fuentes, Instituto Mora, México, 21, 2004, pp. 11-35. El problema con el período virreinal es el libre comercio, que implicaría que ya no alcanza con trabajar en el Archivo General de Indias y se debería visitar los archivos de todos los puertos habilitados.

${ }^{101}$ Con anterioridad, el comercio ultramarino regional sólo se conoce de modo parcial por no contarse con buenos datos para los circuitos portugués, inglés y francés, que en diversos momentos, más o menos prolongados, y con mayor o menor intensidad, frecuentaron las aguas rioplatenses de modo legal. Sea por el asentamiento portugués en la banda norte, sea por contratos y/o tratados entre coronas, sea por urgencias en tiempos de guerra. El abandono de la política de asientos de esclavizados con empresas extranjeras o mixtas pero bajo control extranjero (1748) más la expulsión de los portugueses de la banda norte del río (1777), concentran el flujo de comercio legal en el circuito español. El gran problema con las cifras de períodos anteriores tal vez no sea el contrabando en sí, sino que se utilizan habitualmente sólo las del circuito español.
} 
y la composición de la oferta del comercio practicado desde el complejo portuario rioplatense, sino también llegar a una apreciación bastante ajustada de su intensidad y densidad.

\section{Cierre: una hipótesis en torno al consumo}

Este trabajo no puede tener conclusiones. Habituado a navegar en aguas de la historia económico-social, la investigación me ha llevado a desembarcar en una terra que si bien no me es por completo incognita, impone desafíos que exigen especializaciones de las que carezco: la historia cultural. Lo único prudente es presentar las especulaciones e intuiciones que llevan a la formulación de hipótesis para no afirmar haber llegado a Oriente cuando lo más probable es que me haya topado con algo que, simplemente, no conocía.

Si las especulaciones precedentes invitan a suponer que hay linos europeos para todos, resulta legítimo preguntarse qué pasa con el resto de los textiles identificados en las notas de aduana, ya que son los bienes que dominan y articulan los circuitos, junto con todo lo relacionado con el vestir. Como se adelantó, hay textiles que por las cantidades involucradas tenían que ser de consumo amplio (tal vez decir masivo sea impropio) en tanto que otros debían estar destinados a un público más reducido que utilizándolos marcaban su lugar dentro de su casta de pertenencia. Ello se observa a simple vista en las Tablas 1, 2, 3 y 4 (al final del texto) que presentan los textiles diferenciados por fibra y por tipo de tela. ${ }^{102}$

Hay otros bienes que parecen tener consumidores diferenciados por la cantidad puesta en circulación. Se ven, entre otras, en las categorías 'mercería' 103, 'accesorio de indumentaria' 104, 'mobiliario y decoración'105, 'alimentación'106, 'juego y esparcimiento' ${ }^{107}$ o los impresos ${ }^{108}$. Es en los bienes de escasa

Para un intento de sumar todos los circuitos en los cálculos, v. para el siglo XVII, Z. Moutoukias, Contrabando y control colonial y para el siglo XVIII, F. Jumar, "El comercio ultramarino".

${ }^{102}$ Razones de espacio no permiten desarrollar más este análisis ahora. En un trabajo previo centrado en los textiles, realizado sobre un sondeo parcial de los datos (con lo que las cifras avanzadas allí son incompletas), hay más informaciones sobre el consumo potencial de textiles. Fernando Jumar, "La circulación de textiles desde Buenos Aires entre 1779 y 1783", en Guillermina del Valle Pavón; Antonio Ibarra (Coords.), Redes, corporaciones y mercados hispanoamericanos en la economía global, siglos XVII-XIX, México, Instituto de Investigaciones Dr. José María Luis Mora/CONACyT, 2017, pp. 229-276.

${ }^{103}$ Hasta donde se han podido hasta ahora identificar los 3.603 .812 botones puestos en circulación, hay pocas botonaduras de oro y plata o con decorados costosos (esmaltados, filigranas). También se ve en las cintas, hay para todos los gustos y bolsillos, pero las de seda parecen estar menos representadas. RegAduAR, base 1779-1783.

${ }^{104}$ De los 2.495 abanicos registrados, 1.954 se identifican como ordinarios (estructura de madera, país sin datos), mientras que el resto es con estructura de carey, marfil, maderas doradas y los países de seda, telas pintadas o plumas, hasta donde se puede ver en la fuente. RegAduAR, base 1779-1783.

${ }^{105} \mathrm{P}$. e. los espejos. Circulan 24.379 pero la mayoría parece ser de pequeño formato y con marco de papel o cartón. Luego hay otros ya más grandes, con marco de madera (a veces dorada) o de cristal. Los únicos que parecen ser claramente objetos decorativos importantes son dos "grandes a la chinesca" que se envían a Carmen de Patagones, otros dos que van a Salta "dedicados a Nuestro Señor del Milagro" y un cajón que contenía 8 espejos y cornucopias decorativas con destino en Potosí. RegAduAR, base 1779-1783.

106 Dentro de las bebidas alcohólicas, los licores, que reducidas las botellas y limetas en que circulan equivalen a 72,44 barriles. También el ron (16 barriles), el tintilla ( 5 barriles), el rosolís (76,66 barriles). RegAduAR, base 1779-1783.

${ }^{107}$ P. e. se registran 5 claves ( 2 a Montevideo, y uno a Santiago del Estero, otro a Mendoza y el último a Santa Fe); un monocordio a Córdoba y otro a Santa Fe; un pianoforte para Mendoza; partituras musicales a Salta (10 unidades) y Chile (otras 10); violines para Paysandú, Tucumán, Salta, Corrientes, Gualeguay, Yapeyú, y Potosí. Las cuerdas de guitarra salen en cantidad y hacia todos lados. Bolas de billar a Potosí y Montevideo. RegAduAR, base 1779-1783.

${ }^{108}$ En total se registran 16.289 impresos, que pudieron ser agrupados en tres subcategorías: educación elemental y catequismo, impresos piadosos (tanto para las prácticas profesionales de los religiosos como para las devociones privadas, son libros sagrados, breviarios, misales, novenas, hagiografías, etc.) y libros (hasta donde se los ha identificado, los hay para la realización de estudios en ambos derechos, de historia, diccionarios y muy poca literatura). RegAduAR, base 1779-1783. 
circulación y alto valor social que se puede esperar ver aparecer el consumidor ideal de los efectos de Castilla siempre mencionado en la bibliografía. Pero su cantidad no alcanza para sostener las explicaciones tradicionales sobre el consumo suntuario de las elites como eje articulador del comercio ultramarino y la colonialidad americana.

En relación a los efectos de Castilla, la búsqueda de relaciones entre cantidades de bienes registrados y su calidad y/o uso potencial llevaron a la formulación de una hipótesis en la que se intuye que la integración articulada por la circulación se relaciona con la demanda de bienes que en algunos casos son posicionales y en otros suntuarios, así como que sus precios ${ }^{109}$ deben ser considerados en función de un contexto en el que el gran problema, la subsistencia física, estaba resuelto $^{110}$, lo mismo que el que le seguía en orden de prioridad, el frío. Hay pobreza pero no miseria.

En tal contexto el motor que articula la circulación de bienes de producción extraamericana podría haber sido la necesidad (no el gusto) de las sociedades hispanocriollas por consumir ciertos bienes que tienen la categoría de posicionales más que de suntuarios. ${ }^{111}$ Esos consumos tienen por finalidad evitar la sensación de privación relativa en el acceso a bienes que forman parte de una canasta que determina en buena medida la 'subsistencia social' (aquello que hay que consumir de modo imperativo para ser reconocido como integrante del estamento deseado). En el consumo, el gusto muchas veces está determinado por la consideración social del bien. ${ }^{112}$

\footnotetext{
${ }^{109}$ El tema de los precios ha hecho correr mucha tinta. Su historia fue impulsada en buena medida por la búsqueda de convergencias que revelasen grados de integración en los términos de la economía capitalista. Pero los precios tal vez no quieran decir tanto, o lo mismo, en economías con muy amplios porcentajes de economía natural, que además son el resultado de la convivencia y articulación del mundo indígena y el occidental y en los que el costo de la subsistencia física no tiene el mismo peso.

${ }^{110}$ En Hispanoamérica cuando hay hambre o frío no llegan ni remotamente a alcanzar los niveles europeos y sus crisis de subsistencia, con el consecuente descontento y reacción social. Como es sabido, en Hispanoamérica durante los tiempos modernos los sectores subalternos inclusive llegan a consumir hasta la saciedad alimentos, como la carne de vaca, que en Europa y en las mismas cantidades sólo pertenecen al mundo de posibilidades de la alta nobleza o la más rica burguesía. En Hispanoamérica la gota no es enfermedad de reyes. El acceso al pan blanco era cosa cotidiana, no se lo veía aparecer principalmente en misa y convertido en el cuerpo de la divinidad.

${ }^{111} \mathrm{La}$ etnohistoria ha analizado el problema dentro del mundo indígena en contacto con el occidental. V. p. e. Ana María Presta, "Desde la Plaza a los Barrios. Pinceladas étnicas tras las casas y las cosas. Españoles e indios en la ciudad de La Plata, Charcas 1540-162 [sic]", en Nuevo Mundo Mundos Nuevos, Débats, 2010, DOI: 10.4000/nuevomundo.58926(consulta 05/02/2019). De la misma autora: "Undressing the Coya and Dressing the Indian Woman: Market Economy, Clothing, and Identity in the Colonial Andes, La Plata, Charcas. Late Sixteenth and Early Seventeenth Centuries", en The Hispanic American Historical Review, 90, 2010, pp. 41-47.

${ }^{112}$ Como señalan Gastaldi y Esjaita, la mayor parte de la bibliografía sobre el consumo se ha dedicado a la "trilogía mediterránea" y su imposición en América. A. C. Gastaldi; Mariel Esjaita, "Aproximación a la estructura". La explicación tradicional para el rechazo de la dieta americana se basa en cuestiones de paladar. Por mi parte, prefiero pensar que para muchos migrantes acceder a tales consumos se trató de una conquista social. La enorme mayoría de los migrantes no pertenecían a las elites peninsulares ni mucho menos. No parece desatinado pensar que esas personas en sus lugares de origen más que vino disponían de aguardientes destilados a partir de descartes de frutas (como el orujo), de panificados bastos y que cocinaban con manteca de cerdo antes que con aceite de oliva. Poder obligar a otros a producir para ellos esos bienes que en sus comarcas de origen ellos mismos producían para sus señores les debe haber producido una exquisita sensación de revancha. Nunca se insistirá lo suficiente con que para la mayoría, así hayan quedado en las capas más bajas de la sociedad hispano-criolla, la migración ha de haber sido vivenciada como todo un éxito: escaparon al hambre y al frío, fueron mucho más libres que quienes se quedaron y tuvieron gente que estaba por debajo de ellos en la escala social. Las informaciones circulaban por lo bajo de la sociedad también, con lo que a la memoria del migrante y su transmisión se suma la llegada permanente de noticias frescas, como muestra el libro de Linebaugh y Rediker, y no pocos rioplatenses se habrán lamentado de la suerte de amigos y familiares en la Península ante una hambruna mientras comían un asado, acompañado de pan blanco y vino de Mendoza (Peter Linebaugh; Marcus Rediker, La hidra de la revolución. Marineros, esclavos y campesinos en la historia oculta del Atlántico, Barcelona, Crítica, 2005).
} 
Así, se propone que hay bienes de circulación amplia que determinan la pertenencia a la casta de españoles, con independencia de la posición relativa de los individuos dentro de su estratificación interna. Junto a ellos hay otros bienes que además de posicionales son suntuarios. Estos sirven para señalar diferencias dentro de la casta y circulan en cantidades menores. ${ }^{113}$ La variedad es amplia y las cantidades escasas.

En un mundo en el que el fenotipo no asegura la pertenencia a una casta/estamento $^{114}$, es el tren de vida el que ayuda a identificar y diferenciar. Hay que recordar que en el Antiguo Régimen "el hábito hace al monje". Alguien, sea cual sea su historia genética, que se viste como 'español', vive como 'español' $\mathrm{y}$, sobre todo, es tenido por su comunidad y por el poder en tanto que 'español', es 'español', aún sin la famosa certificación de 'pureza de sangre'. ${ }^{115}$

Silvia Mallo desde la historia social nos enseña cuán distinta podía ser la suerte de un individuo ante la justicia distributiva si se le aceptaba su autopercepción estamental o se le atribuía la que más o menos le favorecía. ${ }^{116}$ En ciertos espacios, hasta podía ser la diferencia entre una condena a muerte por intoxicación por mercurio en Huancavelica o ser el que envía a otros a esa muerte. En Buenos Aires, los libertos mulatos Pesoa que estudia Josefina Mallo llevan tren de vida español y entre sus actividades económicas está la trata de esclavizados ${ }^{117}$.

El sistema de castas no es algo pintoresco para mencionar en algún momento de un manual de historia para después no hacerlo intervenir en las dinámicas de toda la vida americana ni es una clasificación de base "racial" sino posicional en el orden estamental a través de tres variables centrales: la antigüedad de la familia en la grey católica, la situación de vasallaje en relación con la Corona y la condición de libertad. Más o menos rígido en un lugar u otro, con originalidades

\footnotetext{
113 Por ejemplo, y buscando lo más alto de la sociedad, en todo el período observado, se registra la salida de Buenos Aires de un hábito de la Orden de Carlos III para Santiago de Chile, 448 espadines ceremoniales, 3 pelucas empolvadas (dos a Salta y una a Asunción) y 72 bolsas para pelucas que se remiten a Mendoza. También hay 22,94@ de polvos para peluca que se despachan a Montevideo. La cantidad sugiere la detección de un artículo de exportación no considerado hasta ahora, ya que si fuese consumo local la cantidad implicaría que todos los habitantes de Montevideo deberían andar con pelucas empolvadas. Los elegantes utilizaban polvos de arroz, pero si fallaba el nivel adquisitivo se podían usar polvos de trigo y de papas (no tan blancos, más baratos), que podrían ser producidos localmente. RegAduAR, base 1779-1783.

$114 \mathrm{Se}$ observa en la bibliografía que en temas sociales es habitual trasladar a los tiempos modernos los problemas que asocian estratificación en clases sociales y pertenencia étnica. De tan complejo tema sólo necesito rescatar que ser 'español' (= integrante de la casta dominante) no implicaba ser 'blanco', nunca lo fue, ni en los dominios peninsulares. En esos dominios, aunque de modo informal, opera también el sistema de castas: 'españoles' y 'no-cristianos', más esa zona oscura de los 'conversos', con sus estratificaciones internas, pero nunca el 'no-cristiano' más prestigioso va a ocupar lugares similares en la sociedad a sus pares 'españoles'. La pureza de sangre 'española' se demostraba siendo 'cristiano viejo' (= poder demostrar ser al menos la quinta generación de una familia cristiana por sus cuatro costados). Carolina González Undurraga, "De la casta a la raza. El concepto de raza: un singular colectivo de la modernidad. México, 1750-1850", en Historia Mexicana, 60, 3, 239, 2011, pp. 1491-1525. Alejandra Araya Espinoza, “Castas o razas?: imaginario sociopolítico y cuerpos mezclados en la América colonial. Una propuesta desde los cuadros de castas", en Hilderman Cardona Rodas; Zandra Pedraza Gómez (Comps.), Al otro lado del cuerpo: estudios biopolíticos en América Latina, Bogotá, Ediciones Uniandes, 2014, pp. 53-77. Laura Giraudo, Laura, "Casta(s), «sociedad de castas» e indigenismo: la interpretación del pasado colonial en el siglo XX", en Nuevo Mundo Mundos Nuevos, Debates, 2018, DOI: 10.4000/nuevomundo.72080 (consulta 05/02/2019). Claudia Leal; Carl H. Langebaek (Comps.), Historia de raza y nación en América Latina, Bogotá, Ediciones Uniandes, 2010. Max S. Hering Torres, "Color, pureza, raza: la calidad de los sujetos coloniales", en Heraclio Bonilla (Ed.), La cuestión colonial, Bogotá, Universidad Nacional de Colombia, 2011, pp. 451-469.

${ }^{115}$ V. Cecilia Moreyra, "Entre lo íntimo y lo público. La vestimenta en la ciudad de Córdoba a fines del siglo XVIII", en Fronteras de la Historia, 15, 2, 2010, pp. 388-413.

${ }^{116}$ V. Silvia C. Mallo, La sociedad rioplatense ante la justicia. La transición del siglo XVIII al XIX, La Plata, Archivo Histórico de la Provincia de Buenos Aires "Dr. Ricardo Levene", 2004

117 Josefina Mallo, "El nudo en la red: confianza, reputación y negocios familiares. Río de la Plata en el siglo XVIII", en El Taller de la Historia, 12, 2019, pp. 99-121.
} 
regionales ${ }^{118}$ que dan que pensar ${ }^{119}$, pero en todos lados operan claramente las tres castas principales y el resto simplificado mediante el genérico "castas". Sin dudas, hay estratificación dentro de cada una, pero el más noble de los "indios" siempre va a estar por debajo del "español” más pobre, así como los esclavizados y su descendencia liberta estaban por debajo de ambos. ${ }^{120}$ Así, y no me permito ir más allá, el cruce de la casta/estamento con el nivel económico tal vez configure la estratificación social en el período estudiado.

\section{Apéndice. Tablas}

Tabla 1. Textiles al corte de algodón, notas de aduana, Aduana de Buenos

Aires, 1779-1783

\begin{tabular}{|l|r|}
\hline \multicolumn{1}{|c|}{ Textil } & \multicolumn{1}{c|}{ Varas } \\
\hline Chita & 46,50 \\
\hline Cotonía & $1.702,00$ \\
\hline Estampado de algodón & $38.269,50$ \\
\hline Indiana & $8.323,55$ \\
\hline Lienzo de algodón & $102.783,75$ \\
\hline Listadillo de algodón & 600,00 \\
\hline Mahon & $8.211,00$ \\
\hline Media zaraza & $29.595,25$ \\
\hline Muselina & $1.711,50$ \\
\hline Prusiana de algodón & $2.798,75$ \\
\hline Quimón & 74,75 \\
\hline Raso de algodón & 224,00 \\
\hline Ruan de algodón & $1.920,00$ \\
\hline Sarceli & $18.933,78$ \\
\hline Terciopelo de algodón & 358,50 \\
\hline Tripe de algodón & 73,00 \\
\hline Zaracilla & 340,00 \\
\hline Zaraza & $22.507,45$ \\
\hline \multicolumn{1}{|c|}{ Total } & $238.473,28$ \\
\hline
\end{tabular}

Fuente: RegAduAR.

\footnotetext{
118 Para la Nueva España, el esquema ideal, su traducción visual y un denso análisis se puede encontrar en Ilona Katzew, La pintura de castas. Representaciones raciales en el México del siglo XVIII, Singapur, Turner Publicaciones S.L., 2004. 119 P. e. en la Nueva Granada se ve aparecer una gran novedad, los "libres de todos los colores". Ello indica que tempranamente en esa sociedad la diferenciación básica entre las personas dejó de ser la antigüedad de su familia el mundo dominante de valores sino su capacidad de disponer de sí mismas o no.

${ }^{120}$ Un juicio de disenso llevado ante la Audiencia de Buenos Aires muestra estos aspectos. Una mujer que se declara india pura quiere evitar el casamiento de su hijo con una mulata esclava, inclusive si sus amos le conceden la libertad como regalo de bodas. El defensor de la madre, quien es sin dudas quien habla en el expediente aunque asuma la voz de la querellante, sostiene el buen fundamento del disenso con los mismos argumentos que los padres de un español intervendrían para evitar una mésalliance con indígenas. Este caso y otros similares están sintetizados en: Fernando Jumar, "El matrimonio en la época colonial: los juicios de disenso", en Fernando Jumar; Josefina Mallo (Coords.), Raíces Raíces y Alas. Estudios ofrecidos a la Profesora Silvia Mallo, La Plata, UNLP/FaHCE, 2012, pp. 177-194.
} 
Tabla 2. Textiles al corte de lana, notas de aduana, Aduana de Buenos Aires, 1779-1783

\begin{tabular}{|l|r|}
\hline \multicolumn{1}{|c|}{ Textil } & \multicolumn{1}{c|}{ Varas } \\
\hline Amien rayado & 30,00 \\
\hline Anascote & $28.087,00$ \\
\hline Aripes & 180,00 \\
\hline Barracán & 358,00 \\
\hline Bayeta & $36.902,97$ \\
\hline Bayeta de 1 frisa & $36.801,40$ \\
\hline Bayeta de 2 frisas & $152.515,22$ \\
\hline Bayeta de la tierra & $53.240,00$ \\
\hline Bayeta de pellón & $43.550,00$ \\
\hline Bayeta fajuela & $37.464,80$ \\
\hline Bayetilla & $9.675,50$ \\
\hline Bayetón & $2.305,50$ \\
\hline Bocadillo & 128,00 \\
\hline Brillantillo & 147,00 \\
\hline Calámaco & $20.969,50$ \\
\hline Camellón & $54.322,75$ \\
\hline Carmín & $1.345,75$ \\
\hline Carro de oro & $2.927,54$ \\
\hline Castor & $1.824,00$ \\
\hline Chalona & $1.193,00$ \\
\hline Chamelote & 13,00 \\
\hline Cordellate & 967,50 \\
\hline Cristal & $4.403,50$ \\
\hline Damasco & 300,50 \\
\hline Delfina & $1.230,00$ \\
\hline Droguete & 894,00 \\
\hline Durancillo & 941,00 \\
\hline Duray & 323,00 \\
\hline Esguión & \\
\hline &
\end{tabular}

Fuente: RegAduAR.

\begin{tabular}{|l|r|}
\hline \multicolumn{1}{|c|}{ Textil } & \multicolumn{1}{c|}{ Varas } \\
\hline Españoleta & 47,50 \\
\hline Estameña frailesca & $1.803,50$ \\
\hline Eterna & 846,25 \\
\hline Felipichín & 376,75 \\
\hline Felpa de lana & 917,00 \\
\hline Franela & $2.606,68$ \\
\hline Granilla & $7.242,25$ \\
\hline Jerga & $19.438,50$ \\
\hline Lamparilla & $6.353,00$ \\
\hline Lanilla & $2.232,50$ \\
\hline Lienzo de lana & 236,00 \\
\hline Lila & $9.386,75$ \\
\hline Listadillo & 527,83 \\
\hline Manta & 793,00 \\
\hline Monfor & $7.555,30$ \\
\hline Pañete & $9.991,75$ \\
\hline Pañete de la tierra & $2.223,25$ \\
\hline Paño & $92.998,63$ \\
\hline Perdurable & $6.257,00$ \\
\hline Raso de lana & $10.125,50$ \\
\hline Ratina & 508,50 \\
\hline Ropa de la tierra & $68.068,25$ \\
\hline Sagalejo & 363,00 \\
\hline Sarga de lana & $3.625,25$ \\
\hline Sarguilla de lana & 305,50 \\
\hline Sayal & $1.080,75$ \\
\hline Sayalete & 398,00 \\
\hline Sempiterna & $16.760,20$ \\
\hline Serafina & Total \\
\hline Tripe de lana & . \\
\hline & \\
\hline
\end{tabular}


Tabla 3. Textiles al corte de lino, notas de aduana, Aduana de Buenos Aires, 1779-1783

\begin{tabular}{|l|r|}
\hline \multicolumn{1}{|c|}{ Textil } & \multicolumn{1}{c|}{ Varas } \\
\hline Angaripola & $62.007,33$ \\
\hline Bramante & $132.217,25$ \\
\hline Bretaña & $913.311,75$ \\
\hline Bretaña ancha & $113.357,00$ \\
\hline Bretaña angosta & $266.314,00$ \\
\hline Brin & $5.695,00$ \\
\hline Cambrai & $2.400,50$ \\
\hline Cambrayeta & 346,50 \\
\hline Carmín & 59,50 \\
\hline Caserillo & $186.618,50$ \\
\hline Clarín & $14.632,25$ \\
\hline Coleta & $94.283,00$ \\
\hline Cotí & $4.630,00$ \\
\hline Crea & $32.137,50$ \\
\hline Crehuela & $10.674,40$ \\
\hline Crudo & $20.648,08$ \\
\hline Damasco de hilo & 15,00 \\
\hline Drapé & 12,50 \\
\hline Esterín & 585,00 \\
\hline Estopilla & $49.552,16$ \\
\hline Estopilla clarín & $14.274,50$ \\
\hline Estopilla olán & $17.102,00$ \\
\hline Gala & 24,00 \\
\hline
\end{tabular}

\begin{tabular}{|l|r|}
\hline \multicolumn{1}{|c|}{ Textil } & \multicolumn{1}{c|}{ Varas } \\
\hline Gasa de lino & $1.218,50$ \\
\hline Holandilla & 366,00 \\
\hline Imperiosa & 193,00 \\
\hline Lienzo de lino & $69.125,80$ \\
\hline Listadillo de lino & 801,00 \\
\hline Lona & $4.635,00$ \\
\hline Morles & $1.258,00$ \\
\hline Olán & $2.677,00$ \\
\hline Olán batista & $2.044,00$ \\
\hline Olán clarín & $5.391,75$ \\
\hline Platilla & $96.036,88$ \\
\hline Platilla real & $123.854,50$ \\
\hline Presilla & 671,00 \\
\hline Puntibí & $740.957,53$ \\
\hline Royal & $4.199,00$ \\
\hline Ruan & $228.421,45$ \\
\hline Ruan abramantado & $13.938,25$ \\
\hline Sagalejo & $5.767,21$ \\
\hline Sangalete & $6.270,50$ \\
\hline Terliz & 108,00 \\
\hline True & $1.399,00$ \\
\hline Velillo de lino & $1.497,00$ \\
\hline Yle & 20,00 \\
\hline & \\
\hline
\end{tabular}

Fuente: RegAduAR. 
Tabla 4. Textiles al corte de seda, notas de aduana, Aduana de Buenos Aires, 1779-1783

\begin{tabular}{|l|r|}
\hline \multicolumn{1}{|c|}{ Textil } & \multicolumn{1}{c|}{ Varas } \\
\hline Anafalla & $2.342,00$ \\
\hline Bayeta de seda & 36,00 \\
\hline Brocato & 737,35 \\
\hline Burato & $5.797,30$ \\
\hline Calámaco & 20,00 \\
\hline Canutón & 93,00 \\
\hline Carro de oro & 10,00 \\
\hline Chalona & 554,00 \\
\hline Damasco de seda & $4.717,00$ \\
\hline Damasquina & 341,56 \\
\hline Espolín & 876,40 \\
\hline Estambre & 946,25 \\
\hline Estampado de seda & 604,25 \\
\hline Eterna de seda & 125,00 \\
\hline Felpa de seda & $2.240,35$ \\
\hline Felpilla & 5,00 \\
\hline Florentina & 32,00 \\
\hline Fondo & $2.690,95$ \\
\hline Gala & $1.980,62$ \\
\hline Gasa de seda & 756,50 \\
\hline Griseta & 341,00 \\
\hline Grodetur & $2.286,50$ \\
\hline Lama & $2.320,00$ \\
\hline Lienzo de seda & 536,00 \\
\hline Listadillo de seda & $1.002,25$ \\
\hline Lustrina & \\
\hline &
\end{tabular}

\begin{tabular}{|l|r|}
\hline Melania & $7.446,91$ \\
\hline Merlí & $3.159,00$ \\
\hline Morcelina & 60,00 \\
\hline Mué & $2.282,75$ \\
\hline Munetón & 135,00 \\
\hline Musulmana & $1.883,25$ \\
\hline Nobleza & $1.017,50$ \\
\hline Pequinesa & 68,00 \\
\hline Piñuela & 233,25 \\
\hline Princesa & 241,00 \\
\hline Prusiana de seda & 351,00 \\
\hline Raso de seda & $16.370,70$ \\
\hline Saia saia & 12,00 \\
\hline Sarga de Nimes & $5.191,50$ \\
\hline Sarga de seda & 955,50 \\
\hline Sarguilla de seda & $8.324,75$ \\
\hline Segri & 35,00 \\
\hline Setinela & 162,50 \\
\hline Tafetán & $79.431,66$ \\
\hline Tapiz de seda & 171,50 \\
\hline Tela de oro y plata & 808,60 \\
\hline Tercianela de seda & $1.103,50$ \\
\hline Terciopelo de seda & $15.445,02$ \\
\hline Tisú & 964,00 \\
\hline Tornasol & 44,00 \\
\hline Velillo de seda & $5.338,00$ \\
\hline \multicolumn{1}{|c|}{ Total } & $183.522,92$ \\
\hline
\end{tabular}

Fuente: RegAduAR. 


\section{Bibliografía}

Abasolo, Ezequiel, Amor al Real Servicio. Don Joaquín del Pino y la organización del Uruguay hispánico, Madrid/Barcelona, Fundación Rafael del Pino/Marcial Pons Ediciones Jurídicas y Sociales S.A., 2006.

Alioto, Sebastián L., "Dos políticas fronterizas y sus consecuencias: diplomacia, comercio y uso de la violencia del fuerte Carmen de Río Negro (1779-1785", en Prohistoria, 17, 21, 2014, pp. 55-84.

Araya Espinoza, Alejandra, “¿Castas o razas?: imaginario sociopolítico y cuerpos mezclados en la América colonial. Una propuesta desde los cuadros de castas", en Cardona Rodas, Hilderman; Pedraza Gómez, Zandra (Comps.). Al otro lado del cuerpo: estudios biopolíticos en América Latina, Bogotá, Ediciones Uniandes, 2014, pp. 53-77.

Assadourian, Carlos Sempat, "Integración y desintegración regional en el espacio colonial. Un enfoque histórico", en EURE, Revista Latinoamericana de Estudios Urbanos Regionales, 2, 4, 1972, pp. 11-24.

Barba, Enrique, Don Pedro de Cevallos. Gobernador de Buenos Aires y virrey del Río de la Plata, La Plata, Facultad de Humanidades y Ciencias de la Educación, 1937.

Barba, Fernando Enrique, Aproximación al estudio de los precios y salarios en Buenos Aires desde fines del siglo XVIII hasta 1860. Series y problemas en torno al tratamiento de los mismos, La Plata, Editorial de la UNLP/Fundación del Banco Municipal de La Plata, 1999.

Belloto, Manuel Lelo, Correio Marítimo hispano-americano. A carreia de Buenos Aires (1767-1779), Assis (Brasil), Universidade de Assis, 1971.

Bentancur, Arturo Ariel, "Buenos Aires y Montevideo coloniales: entre la comunidad y la controversia", en Silva, Hernán A. (Dir.), Los caminos del Mercosur. Historia económica regional. Etapa colonial, México, Instituto Panamericano de Geografía e Historia, 2004, pp. 427-448.

Bentancur, Arturo Ariel, "La provisión de servicios en el puerto colonial de Montevideo: alcances y limitaciones de una fuente local de riqueza", en Anuarios de Estudios Americanos, 53, 2, 1996, pp. 123-145.

Bentancur, Arturo Ariel, El puerto colonial de Montevideo, 2 tomos, Montevideo, Facultad de Humanidades y Ciencias de la Educación, 1997-1998.

Birolo, Pablo, Militarización y política en el Río de la Plata colonial: Cevallos y las campañas militares contra por portugueses, 1756-1778, Buenos Aires, Prometeo Libros, 2014.

Bonialian, Mariano, China en América: bienes, mercados, comercio y cultura del consumo desde México hasta Buenos Aires, Buenos Aires, Biblos/Instituto Mora, 2014. 
Camarda, Maximiliano, "Algunos datos sobre el comercio ultramarino salido del complejo portuario rioplatense", en El Taller de la Historia, 12, 2019, pp. 185207.

Camarda, Maximiliano, "La Región Río de la Plata y el comercio ultramarino durante las últimas décadas del siglo XVIII: circulación comercial, mercancías y actores", Tesis de doctorado inédita, Universidad Nacional de La Plata, 2015, http://www.memoria.fahce.unlp.edu.ar/tesis/te.1181/te.1181.pdf $\quad$ (consulta 17/11/2018).

Cano Borrego, Pedro Damián, "La Casa de Moneda de Santiago de Chile en el siglo XVIII", en Anuario. Asociación Numismática de Chile, 2010-2017, pp. 30-42.

Céspedes del Castillo, Guillermo, "Lima y Buenos Aires. Repercusiones económicas y políticas de la creación del virreinato del Plata", en Anuario de Estudios Americanos, 3, 1946, pp. 667-874.

Djenderedjian, Julio César; Frid, Carina; Martirén, Juan Luis, "Los registros conventuales como fuente para la historia económica. Aproximaciones metodológicas a partir del caso de Santa Fe (Argentina), 1700-1850”, en Historia Crítica, 72, 2019, 3-25.

Djenderedjian, Julio; Martirén, Juan Luis, "Los aforos de alcabalas como fuente útil para el estudio de los precios en el Río de la Plata: metodología e interpretación sobre su evolución en la etapa virreinal (1772-1810)", en Folia Histórica del Nordeste, 26, 2016, pp. 74-94, http://www.scielo.org.ar/scielo.php?script=sci arttext\&pid=S0325$\underline{82382016000200005}$ (consulta 06-04-2018).

Fàbregas Roig, Josep, "El libre comercio de Cataluña con América durante la guerra de las trece colonias, 1779-1783", en Martínez Shaw, Carlos; Alfonso Mola, María (Coords.), España en el comercio marítimo internacional (siglos XVIIXIX). Quince estudios, Madrid, UNED, 2010, pp. 394-425.

Galarza, Antonio, "Relaciones interétnicas y comercio en la frontera sur rioplatense. Partidas indígenas y transacciones comerciales en la Guardia de Chascomús (1780-1809)", en Fronteras de la Historia, 17, 2, 2012, pp. 102-128.

Garavaglia, Juan Carlos, “El comercio virreinal 1779-1784”, Tesis de Licenciatura inédita, Universidad de Buenos Aires, 1970, http://repositorio.filo.uba.ar/bitstream/handle/filodigital/4206/uba_ffyl_t_1970_s e_Garavaglia.pdf?sequence $=3 \&$ isAllowed $=y$ ( consulta 10/03/2019).

Garavaglia, Juan Carlos, Mercado interno y economía colonial (Tres siglos de historia de la yerba mate), México, Grijalbo, 1983.

Gastaldi, Ana Clara; Esjaita, Mariel, "Aproximaciones a la estructura socioeconómica desde un enfoque sociocultural: el consumo como vía a la identidad en el Río de la Plata virreinal", en El Taller de la Historia, 12, 2019, pp. 243-266. 
Gelman, Jorge; Moraes, María Inés, "Las reformas borbónicas y las economías rioplatenses: cambio y continuidad", en Gelman, Jorge; Llopis, Enrique; Marichal, Carlos (Coords), Iberoamérica y España antes de las independencias, 1700-1820: crecimiento, reformas y crisis, México, Instituto de Investigaciones "Dr. José María Luis Mora”, 2014, pp. 31-74.

Giraudo, Laura, "Casta(s), «sociedad de castas» e indigenismo: la interpretación del pasado colonial en el siglo XX", en Nuevo Mundo Mundos Nuevos, Debates, 2018, DOI: $10.4000 /$ nuevomundo.72080 (consulta 06-04-2019).

González Undurraga, Carolina, "De la casta a la raza. El concepto de raza: un singular colectivo de la modernidad. México, 1750-1850", en Historia Mexicana, 60, 3, 239, 2011, pp. 1491-1525.

Hering Torres, Max S., "Color, pureza, raza: la calidad de los sujetos coloniales", en Bonilla, Heraclio (Ed.), La cuestión colonial, Bogotá, Universidad Nacional de Colombia, 2011, pp. 451-469.

Jiménez, Alfredo, El Gran Norte de México. Una frontera imperial en la Nueva España (1540-1820), Madrid, Tébar, 2006.

Jumar, Fernando, “«Buscar la vida» en el Río de la Plata. Marcelino Callexas Sanz, 1757-1820", en Illes $i$ Imperis, 18, 2016, pp. 44-76, http://www.raco.cat/index.php/IllesImperis/article/view/208050023/403427 (consulta 10/02/2019).

Jumar, Fernando, "El comercio atlántico del Río de la Plata, 1680-1777. El circuito legal español. Las fuentes utilizadas y su tratamiento", en América Latina en la Historia Económica. Boletín de fuentes, Instituto Mora, México, 21, 2004, pp. 1135, DOI: http://dx.doi.org/10.18232/alhe.v11i1.332 (consulta 10/02/2019).

Jumar, Fernando, "El comercio ultramarino por el complejo portuario rioplatense y la economía regional, 1714-1778", en Magallánica. Revista de Historia Moderna, 3, 5, 2016, p. 171-259, http://fh.mdp.edu.ar/revistas/index.php/magallanica/article/view/2006 (consulta 10/02/2019).

Jumar, Fernando, "El espacio colonial peruano en la historiografía sobre circulación mercantil", en História Ecônomica \& História de Empresas, 17, 2, 2014, pp. 475534, http://www.abphe.org.br/revista/index.php/rabphe/issue/view/40 (consulta 03/02/2019).

Jumar, Fernando, "El matrimonio en la época colonial: los juicios de disenso", en Jumar, Fernando; Mallo, Josefina (Coords.), Raíces Raíces y Alas. Estudios ofrecidos a la Profesora Silvia Mallo, La Plata, UNLP/FaHCE, 2012, pp. 177194.

Jumar, Fernando, "El precio de la fidelidad. La Guerra de Sucesión en el Río de la Plata, los intereses locales y el campo Borbón", en Molinié, Annie; Merle, Alexandra (Dirs.), L'Espagne et ses guerres. De la fin de la Reconquête aux guerres de l'Indépendance, París, Presses de l'Université Paris/Sorbonne, 2004, 
pp. 203-236, http://www.fuentesmemoria.fahce.unlp.edu.ar/libros/pm.9/pm.9.pdf (consulta 05/02/2019).

Jumar, Fernando, "El primer boom de la exportación de cueros y la sociedad local. Río de la Plata. Fines del siglo XVII, comienzos del siglo XVIII", en XXI Jornadas de Historia Económica, Asociación Argentina de Historia Económica/Universidad Nacional de Tres de Febrero, Caseros, 2008, http://www.fuentesmemoria.fahce.unlp.edu.ar/trab_eventos/ev.712/ev.712.pdf (consulta 05/02/2019).

Jumar, Fernando, "La circulación de textiles desde Buenos Aires entre 1779 y 1783", en Valle Pavón, Guillermina del; Ibarra, Antonio (Coords.), Redes, corporaciones y mercados hispanoamericanos en la economía global, siglos XVII-XIX, México, Instituto de Investigaciones Dr. José María Luis Mora/CONACyT, 2017, pp. 229276.

Jumar, Fernando, Le commerce atlantique au Río de la Plata, 1680-1778, 2da. ed. Aumentada, $1^{\mathrm{a}}$ ed. Electrónica, La Plata, UNLP, 2010, http://www.memoria.fahce.unlp.edu.ar/tesis/te.364/te.364.pdf (consulta 14/08/2018).

Jumar, Fernando. "Hay para todos. La circulación intra y extra-regional de Río de la Plata observada desde la Aduana de Buenos Aires, 1779-1783", en El Taller de la Historia, 12, 2019, pp. 267-315.

Jumar, Fernando; Kraselsky, Javier, "Las esferas del poder. Hacendados y comerciantes ante los cambios de la segunda mitad del siglo XVIII", en Anuario del Instituto de Historia Argentina, Universidad Nacional de La Plata, 7, 2007, pp. 31-58, http://www.memoria.fahce.unlp.edu.ar/art_revistas/pr.672/pr.672.pdf (consulta 03/02/2019).

Jumar, Fernando; Paredes, Isabel, "El comercio intrarregional en el complejo portuario rioplatense: el contrabando visto a través de los comisos, 1693-1777", en América Latina en la Historia Económica, 29, 2008, pp. 33-99, http://alhe.institutomora.edu.mx/index.php/ALHE/article/view/388/546 (consulta 12/02/2019).

Jumar, Fernando; Sandrín, María Emilia, "El gasto público como dinamizador de la economía local. Río de la Plata, en la primera mitad del siglo XVIII", en Sánchez Santiró, Ernest (Coord.), El gasto público en los Imperios Ibéricos, siglo XVIII, México, Instituto Mora, 2015, pp. 205-272.

Katzew, Ilona, La pintura de castas. Representaciones raciales en el México del siglo XVIII, Singapur, Turner Publicaciones S.L., 2004.

Kossok, Manfred, El Virreynato del Río de la Plata. Su estructura económica y social, Buenos Aires, Editorial Futuro, 1959.

Kraselsky, Javier, "Las estrategias de los actores del Río de la Plata: las Juntas y el Consulado de comercio de Buenos Aires a fines del Antiguo Régimen (17481809)", Tesis de Doctorado inédita, Universidad Nacional de La Plata, 2011, 

10/11/2018).

Leal, Claudia; Langebaek, Carl H., (Comps.), Historia de raza y nación en América Latina, Bogotá, Ediciones Uniandes, 2010.

León Solís, Leonardo, "La guerra contra el malón en Chile, Cuyo y Buenos Aires, 1750-1800", en Cuadernos de Historia, Universidad de Chile, 17, 1997, pp. 7-67.

Lespagnol, André, Messieurs de Saint-Malo, une élite négociante au temps de Louis XIV, 2 Tomos, Rennes, Presses Universitaires de Rennes, 1997.

Linebaugh, Peter; Rediker, Marcus, La hidra de la revolución. Marineros, esclavos y campesinos en la historia oculta del Atlántico, Prólogo de Joseph Fontana, Traducción de Mercedes García Garmilla, $1^{a}$ ed. en inglés 2000, Barcelona, Crítica, 2005.

Mallo, Josefina. "El nudo en la red: confianza, reputación y negocios familiares. Río de la Plata en el siglo XVIII", en El Taller de la Historia, 12, 2019, pp. 99-121.

Mallo, Silvia C. La sociedad rioplatense ante la justicia. La transición del siglo XVIII al XIX, La Plata, Archivo Histórico de la Provincia de Buenos Aires "Dr. Ricardo Levene", 2004.

Mitre, Bartolomé, Historia de Belgrano y de la Independencia Argentina, $4^{\mathrm{a}}$ ed. definitiva, 3 tomos, Buenos Aires, Editorial Félix Lajouane, 1887.

Moreyra, Cecilia, "Entre lo íntimo y lo público. La vestimenta en la ciudad de Córdoba a fines del siglo XVIII", en Fronteras de la Historia, 15, 2, 2010, pp. 388-413.

Morineau, Michel, "Tonnage et cargaison. Codicille à une étude de la Carrera de Indias", en Revue belge de philologie et d'histoire, 79, 4, 2001, pp. 1159-1211.

Morineau, Michel, Jauges et méthodes de jauge anciennes et modernes, París, Librairie Armand Collin, 1966.

Moutoukias, Zacarías, Contrabando y control colonial en el siglo XVII, Buenos Aires, CEAL, 1988.

Otero Lana, Enrique, "La escuadra corsaria del Consulado de Cádiz (1779-1783) y su actividad en América", en Derroteros de la Mar del Sur, 13, 2005, pp. 113121.

Polvarini de Reyes, Alicia, "Mercado interno y región Moquegua y las rutas del aguardiente de uva en los siglos XVIII y XIX", en Guerra Martinière, Margarita; Mazzeo de Vivó, Cristina; Rouillon Almeida, Denisse (Eds.), Historias compartidas: economía, sociedad y poder, siglos XVI-XX: actas del primer encuentro de historia Perú-Argentina, Lima, PUCP/Instituto Riva-Agüero, 2007, p. $455-491$. 
Possamai, Paulo, Colonia del Sacramento. Vida cotidiana durante la ocupación portuguesa, Montevideo, Torre del Vigía Ediciones, s/f [post. 2007].

Prado, Fabrício, A Colônia do Sacramento: o extremo sul da América portuguesa no século XVIII, Porto Alegre, F. P. Prado, 2002.

Prado, Fabrício, Edge of Empire. Atlantic network and revolution in Bourbon Río de la Plata, Oakland (California, EEUU), University of California Press, 2015.

Presta, Ana María, "Desde la Plaza a los Barrios. Pinceladas étnicas tras las casas y las cosas. Españoles e indios en la ciudad de La Plata, Charcas 1540-162 [sic]", en Nuevo Mundo Mundos Nuevos, Débats, 2010, DOI: 10.4000/nuevomundo.58926 (consulta 10/02/2019).

Presta, Ana María, "Undressing the Coya and Dressing the Indian Woman: Market Economy, Clothing, and Identity in the Colonial Andes, La Plata, Charcas. Late Sixteenth and Early Seventeenth Centuries", en The Hispanic American Historical Review, 90, 2010, pp. 41-47.

Quarleri, Lía, Rebelión y guerra en las fronteras del Plata: guaraníes, jesuitas e imperios coloniales, Buenos Aires, Fondo de Cultura Económica de Argentina S.A., 2009.

Ravignani, Emilio, "El Virreinato del Río de la Plata (1776-1810)", en Levene, Ricardo (Dir. gral.), Historia de la Nación Argentina (Desde los orígenes hasta la organización definitiva en 1862), Tomo IV, $1^{\text {a }}$ sección, $1^{\text {a }}$ edición 1940, Buenos Aires, El Ateneo, 1961, pp. 11-195.

Roca, José Luis, Ni con Lima ni con Buenos Aires. La formación de un Estado nacional en Charcas, La Paz, Ed. Plural/IFEA, 2007.

Ruiz Ibáñez, José Javier, Las vecindades de las Monarquías Ibéricas, Madrid, Fondo de Cultura Económica, 2013.

Saguier, Eduardo, Genealogía de la tragedia argentina (1600-1900). Auge y Colapso de un fragmento de estado o la violenta transición de un orden imperialabsolutista a un orden nacional-republicano, Tomo II, sección G, Capítulo 21, https://www.er-saguier.org/obras/gta/Tomo-II/Seccion-G/Cap-21/0-BUR-12.pdf (consulta 05/02/2019).

Sandrín, María Emilia, "La demanda de bienes y servicios para la Corona y la navegación ultramarina en el complejo portuario rioplatense y la dinamización de la economía regional, 1680-1810", Tesis de Doctorado inédita, Universidad Nacional de La Plata, 2016, http://www.memoria.fahce.unlp.edu.ar/tesis/te.1217/te.1217.pdf ～(consulta 03/02/2019).

Sandrín, María Emilia, Bizcocheras, lancheros y demás... Los estímulos económicos de la guerra para los sectores medios y bajos del complejo portuario rioplatense, 1735-1737, Saarbrücken, Editorial Académica Española, 2011. 
Santos, Corcino Medeiros dos, O Rio de Janeiro e a Conjuntura Atlântica, Rio de Janeiro, Expressão e Cultura, 1993.

Schlez, Mariano Martín, "El comercio de un monopolista. Volumen, contenido y sentido de la circulación según un estudio de caso (Río de la Plata, 1770-1820)", en Anuario de estudios americanos, 73, 1, 2016, pp. 163-198.

Schröter, Bernd; Büschges, Christian (Eds.), Beneméritos, aristócratas y empresarios. Identidades y estructuras sociales de las capas altas urbanas en América hispánica, Madrid, Verbuert-Iberoamericana, 1999.

Serrato Higuera, Rubén Darío, "Las armas del dinero: mecanismos de financiación y administración en la segunda expedición de Pedro de Cevallos al Río de la Plata, 1777”, Tesis de Maestría inédita, Universidad Nacional de Tres de Febrero, 2017. Existe una versión impresa: Las armas del dinero. El estado fiscal-militar español del siglo XVIII, Saarbrücken, Editorial Académica Española, 2018.

Silva, Hernán Asdrúbal, "Consideraciones sobre el comercio ilícito en el Río de la Plata", en Cuadernos del Sur, Universidad Nacional del Sur, Bahía Blanca (Argentina), 17, 1984, pp. 101-116.

Silva, Hernán Asdrúbal, "Hamburgo y el Río de la Plata. Vinculaciones económicas a fines de la época colonial", en Jahrbuch für Geschichte von Stäat, Wirtschaft und Gesellschaft Lateinamerikas, 21, 1984, pp. 189-209.

Silva, Hernán Asdrúbal, "La estructuración del comercio y la navegación desde el Río de la Plata a Cuba", en Anuario de Estudios Americanos, 51, 2, 1994, pp. 6173.

Silva, Hernán Asdrúbal, El comercio entre España y el Río de la Plata (1778-1810), Madrid, Banco de España, 1993.

Torre Revello, José, "Los Navíos de Registro en el Río de la Plata. 1500-1700”, en Boletín de la Academia Nacional de la Historia (Argentina), 34, Buenos Aires, 1963, pp. 529-559.

Torre Revello, José, "Un contrabandista del siglo XVII en el Río de la Plata", en Revista de Historia de América, Instituto Pan-Americano de Geografía e Historia, Comisión de Historia, México, 1958, pp. 121-130.

Vaccani, María Evangelina, "La Real Aduana de Buenos Aires y la quiebra de su primer administrador: Francisco Ximénez de Mesa. Dominación y control en una sociedad de Antiguo Régimen", en El Taller de la Historia, 12, 2019, pp. 58-86.

Villalobos, Sergio, "La política comercial del virrey Cevallos y la reacción chilenoperuana", en Trabajos y Comunicaciones, 11, 1963, pp. 163-177.

Wasserman, Martín L. E, "Las prácticas crediticias en Buenos Aires durante el siglo XVII. Instrumentos, contextos relacionales e instituciones en una sociedad emergente", 2 tomos, Tesis de Doctorado inédita, Universidad de Buenos Aires, 2014. 
Wasserman, Martín L. E, "Más allá de las redes: deudas y contratos en Buenos Aires durante el temprano siglo XVII", Tesis de Maestría inédita, Universidad de San Andrés, 2009 